\title{
Medievalista
}

Online

$23 \mid 2018$

Número 23

\section{¿Representar la legitimidad? Objetos, símbolos y comunicación en las ceremonias públicas del reinado de Fernando I de Aragón}

Representing Legitimacy? Artifacts, Symbols and Communication in Public Royal Ceremonies during the Reign of Ferdinand I of Aragon

\section{Víctor Muñoz Gómez}

\section{OpenEdition}

Journals

Edición electrónica

URL: http://journals.openedition.org/medievalista/1653

DOI: $10.4000 /$ medievalista. 1653

ISSN: $1646-740 \mathrm{X}$

Editor

Instituto de Estudos Medievais - FCSH-UNL

Edición impresa

Fecha de publicación: 1 enero 2018

Referencia electrónica

Víctor Muñoz Gómez, « ¿Representar la legitimidad? Objetos, símbolos y comunicación en las ceremonias públicas del reinado de Fernando I de Aragón », Medievalista [En línea], 23 | 2018, Puesto en línea el 07 mayo 2018, consultado el 04 mayo 2019. URL : http://journals.openedition.org/ medievalista/1653 ; DOI : 10.4000/medievalista.1653

Este documento fue generado automáticamente el 4 mayo 2019.

(C) IEM 


\section{¿Representar la legitimidad? Objetos, símbolos y comunicación en las ceremonias públicas del reinado de Fernando I de Aragón}

Representing Legitimacy? Artifacts, Symbols and Communication in Public Royal Ceremonies during the Reign of Ferdinand I of Aragon

Víctor Muñoz Gómez

\section{NOTA DEL EDITOR}

Data recepção do artigo / Received for publication: 16-03-2017

Data aceitação do artigo / Accepted in revised form: 15-12-2017

$$
\begin{array}{r}
\text { ¿Representar la legitimidad? Objetos, símbolos y } \\
\text { comunicación en las ceremonias públicas del } \\
\text { reinado de Fernando I de Aragón / Representing } \\
\text { Legitimacy? Artifacts, Symbols and } \\
\text { Communication in Public Royal Ceremonies during } \\
\text { the Reign of Ferdinand I of Aragon } \\
\text { Víctor Muñoz Gómez }
\end{array}
$$

Cuando el infante Fernando de Castilla fue finalmente proclamado rey de Aragón en Caspe el 28 junio de 1412, se cerraba el interregno iniciado en los reinos de la Corona de Aragón por la muerte sin un heredero definido del rey Martín I en mayo de 1410. La decisión de los compromisarios reunidos en el castillo hospitalario de la bailía de Caspe ratificaba la legitimidad de los mejores derechos a la sucesión al trono por el candidato castellano frente a los del resto de candidatos. No obstante, más allá del proceso de negociación entre las elites de las sociedades políticas de los reinos peninsulares de la Corona de Aragón que desembocó en la sentencia de Caspe, el interregno había supuesto 
un tenso período de enfrentamiento y guerra civil entre las distintas facciones que apoyaron a los principales candidatos al trono, fundamentalmente Jaume de Aragón, conde de Urgell, Luis de Anjou, conde de Calabria, y, en último término, el infante Fernando. Como es bien conocido, el asentamiento firme de Fernando I en el trono de Aragón no quedó certificado hasta la derrota del levantamiento del conde de Urgell contra él en octubre de 1413, por más que los apoyos que Jaume de Aragón logró movilizar en la Corona de Aragón contra el monarca de origen castellano tras Caspe fueron ciertamente escasos frente al mayoritario acatamiento y sustento que recibió Fernando ${ }^{1}$.

2 Me interesa señalar que las especiales circunstancias del ascenso al trono de Aragón de Fernando "el de Antequera" frente a unos candidatos que, a priori, contaban con mejores y más fuertes apoyos iniciales que él para acabar siendo proclamados como reyes han conducido a focalizar no poco interés historiográfico en el debate sobre la legitimidad del derecho a ceñir la corona de Fernando de Castilla frente a, fundamentalmente, el de Jaume de Aragón, el peso de la fuerza en el resultado final de del compromiso de Caspe o su carácter pragmático. No es mi objetivo aquí entrar en el debate de cuál fue el elemento decisivo que terminó por decantar el resultado de la proclamación de Fernando de Castilla en Caspe como persona con mejor derecho a la sucesión de la casa real de Aragón. Es suficiente referirse, en este sentido, a las opiniones que diferentes autores han desarrollado en las reuniones científicas y publicaciones auspiciadas en torno a los centenarios del interregno y el compromiso de Caspe entre 2010 y 2012 ya citadas ${ }^{2}$. Si prevaleció el grado de madurez de los agentes sociales y de las organizaciones de la monarquía catalanoaragonesa para canalizar hacia una solución legalista e institucionalizada las tensiones generadas en torno a la elección o si se impuso la orientación de determinados grupos de las elites sociopolíticas de la Corona a lo largo del interregno hasta la agrupación de un sector mayoritario de ellos alrededor de un candidato con derecho al trono pero ante todo valioso para los intereses generales de la monarquía de sus sociedades políticas ${ }^{3}$.

3 A resultas de esta discusión historiográfico, uno de los aspectos que más ha atraído mi atención como investigador ha sido el relativo a los esfuerzos que el nuevo soberano habría tenido que realizar para afirmar sus derechos legítimos a ceñir la corona ante sus súbditos a lo largo de todo su breve reinado, concluido con su abrupto fallecimiento por enfermedad el 2 de abril de 1416. Pude realizar un primer acercamiento al discurso propagandístico generado en torno a la persona de Fernando "el de Antequera", de cara a la afirmación de su liderazgo político y social, primero en Castilla, luego en la Corona de Aragón ${ }^{4}$. A partir de él, se puso de manifiesto la potencialidad que ofrecía el estudio tanto de los conceptos como de las formas de comunicación simbólica que constituyeron de manera efectiva ese mensaje de legitimación elaborado por el nuevo soberano de Aragón de origen castellano y su entorno para los agentes individuales y colectivos de las sociedades políticas de su monarquía. En un primer estudio fue posible presentar esa propuesta de análisis y su posible alcance ${ }^{5}$. Así, en estas páginas me propongo profundizar en esa problemática ligada a los principios y los medios de representación de sus derechos legítimos al trono de Aragón que el infante Fernando de Castilla promocionó y exhibió ante sus súbditos. 


\section{Comunicación simbólica y propaganda: fuentes para un reinado}

Como señalaba más arriba, me interesa no sólo incidir en la valoración de las nociones centrales manejadas para la exaltación de la majestad y legitimidad del rey Fernando, sino ir un paso más allá al preguntarme por la forma en que tuvieron efecto muchos de los procesos de comunicación política entre el nuevo monarca y los agentes sociales de sus nuevos reinos de la Corona de Aragón entre 1412 y 1416. Para ello parece especialmente apropiado analizar los espectáculos elaborados para tal fin, la celebración de la presencia, dignidad y autoridad de la persona regia, durante su reinado. La monumentalidad y grandiosidad de muchos de ellos daban lugar a una plasmación de enorme plasticidad y efectividad comunicativa de la argumentación conceptual y simbólica manejada por la monarquía para la manifestación ceremonial de su poder ${ }^{6}$, de modo que el análisis de dichos festejos podría darnos algunas de las claves en torno al discurso de legitimación elaborado alrededor del rey Fernando y desplegado ante sus súbditos.

5 Así, no son pocas las aportaciones historiográficas para las monarquías bajomedievales ibéricas en general y para la Corona de Aragón más en particular que se han ocupado de incidir en el papel de dichos espectáculos ligados al ceremonial real. Más aún, la valoración propagandística de los desarrollados en el reinado de Fernando I de Aragón, a partir de las posibles necesidades legitimadoras del rey ante la falta de apoyo unánime en su ascenso al trono, ha dado no pocos frutos ${ }^{7}$. Entonces, a la hora de elegir el objeto de estudio a tratar, se ha tenido en cuenta, por un lado, el peso de esta trayectoria de análisis alrededor del problema que aquí nos ocupa y, por otro lado, la disponibilidad y potencialidad contrastada de fuentes documentales y literarias aptas para afrontar esta investigación. Por ello, se decidió atender al simbolismo desplegado en las representaciones escénicas encargados para ellas, formas de arquitectura efímera, juegos caballerescos, etc. desarrollados en, prioritariamente, dos contextos especialmente destacados para el despliegue simbólico del discurso propagandístico del rey. Primero, la propia coronación de Fernando I y de su esposa, Leonor de Alburquerque, en Zaragoza en febrero de 1414. En segundo término, las entradas reales del monarca, la reina consorte y el príncipe heredero en las principales ciudades de la monarquía catalanoaragonesa entre 1412 y 1415 motivadas por distintas circunstancias.

6 Así, ya desde los años 80 del siglo XX distintos autores habían puesto de relieve el valor central, como expresión más acabada de representación de la legitimidad del rey Fernando, tras la derrota y condena del rebelde conde de Urgell, de los festejos ligados a su coronación. Así evocó de forma muy somera Angus MacKay algunos de los principios argumentales manejados en ella y ligados a la devoción a la Virgen María por parte de Fernando ${ }^{8}$. Tales celebraciones, en cualquier caso, se desarrollaron en Zaragoza entre los días 10 y 19 febrero de 1414 en diferentes escenarios dentro la capital aragonesa, destacadamente, la iglesia catedral, la Seo, y el palacio de la Aljafería, pero sin olvidar el propio papel de las calles de la urbe como espacio escénico de primer orden de desfiles procesionales y entremeses. Estos aspectos han sido analizados con mayor profundidad, prioritariamente, por Roser Salicrú, en un sentido más ligado a la preparación logística de todos los actos de la coronación, y por Francesc Massip, desde el punto de vista del 
estudio de los espectáculos escénicos desplegados en esos días y de su contenido simbólico?.

7 En ese sentido, los investigadores citados han podido beneficiarse del acceso a dos conjuntos de fuentes. Por una parte, como bien denota el trabajo de la profesora Salicrú, los registros documentales de la Corona, tanto aquellos de la cancillería como los de tipo contable formados bajo la supervisión del maestre racional del rey, conservados en el Archivo de la Corona de Aragón en Barcelona. Éstos aportan noticias en general someras, ligadas al coste de la preparación de los espectáculos escénicos o la petición del envío a Zaragoza desde algunas ciudades de la monarquía ciertos artilugios ya utilizados en otros entremeses con el fin de ser reutilizados durante los juegos y diversiones que se preparaban ${ }^{10}$. Todo ello nos aporta una cierta idea en torno a las instrucciones emanadas desde el entorno regio para el diseño de unos fastos que obedecían a una lógica de comunicación simbólica claramente intencional y que pretendía primar la expresión de ciertas ideas de un modo muy claro en beneficio de la imagen pública del rey ${ }^{11}$. Por otra parte, al fin, el conocimiento de los acontecimientos de la coronación y del ceremonial en ellos desplegado se basa, en cambio, en fuentes de naturaleza cronística. De hecho, son las crónicas reales castellanas las que más detalladamente han dado cuenta del relato de las fiestas de la coronación a partir de la narración de Álvar García de Santa María en su Crónica de Juan II de Castilla, habiéndose conservado la parte del texto relativa a dicha coronación en los manuscritos editados por Donatella Ferro ${ }^{12}$.

8 Por lo que se refiere a las entradas reales, este tipo de acontecimiento ceremonial ha sido objeto de gran interés por parte de los estudiosos de la comunicación política y la representación del poder en el Occidente bajomedieval. Los distintos estudios que ha discurrido en torno al sentido de los actos y espectáculos desarrollados alrededor de la recepción de las personas reales en las ciudades de su monarquía han subrayado el carácter fundamentalmente urbano de las ceremonias de entrada real. Así, aunque sin duda su cometido era remarcar la dignidad y honra del monarca, eran las autoridades municipales las que primordialmente controlaban la organización de dichos espectáculos, atendiendo a prácticas y tradiciones de recibimiento y representación del rey, en buena medida, autónomas. De este modo, a través de las ceremonias de entrada real, los grupos dirigentes de las sociedades políticas urbanas pretendían resaltar prioritariamente la propia identidad y honra de la ciudad en su relación con el rey dentro del cuerpo político de la monarquía, en términos variables, de sometimiento, de acatamiento pero también de negociación o de pacto, de modo que el lenguaje simbólico desgranado en dichas ceremonias servía para escenificar los distintos sentidos cambiantes de los vínculos entre la ciudad y la Corona ${ }^{13}$.

9 En esta línea se ha movido la interpretación de quien ha estudiado de forma más reciente y de forma más exhaustiva muchas de esas ceremonias de entrada real en Barcelona desde el final del siglo XIV y durante el siglo XV, Miguel Raufast. Éste se ha ocupado, a partir de documentación real del Archivo de la Corona de Aragón y de la de origen municipal barcelonesa (Llibres del Consell y Clavaria, fundamentalmente), complementada con noticias cronísticas, de analizar de forma comparada las prácticas de representación en dicha ciudad ligadas a la entrada real con ocasión de la protagonizada por Martín I en 1397 y luego por Fernando I en 1412, amén de las realizadas por sus sucesores Trastámara a lo largo del siglo XV, con el fin de detectar posibles modificaciones en el sentido del ceremonial que pudieran denotar nuevas necesidades representativas ligadas a la legitimación dinástica de estos monarcas de origen castellano ${ }^{14}$. Sin embargo, las 
posibilidades de estudio comparado no quedan aquí. Centrándose en aspectos escénicos y de representación simbólica, también Francesc Massip ha tratado las entradas reales en Barcelona en el último tercio del siglo XIV y el siglo XV, ampliando esta pesquisa también a las entradas realizadas en la ciudad de Valencia ${ }^{15}$. En ese sentido, la conservación en Valencia entre la documentación municipal de los llibres de l'entrada relativos a la realizada por Martín I en 1402 y a las que protagonizaron Fernando I, su esposa y el infante primogénito Alfonso y su prometida, la infanta María de Castilla, para su matrimonio en la ciudad entre diciembre de 1414 y los primeros días de 1415, ambos recientemente editados ${ }^{16}$, nos dotan de un material de extraordinaria riqueza para el análisis de tales aspectos. A partir de dichos libros es posible hacer un seguimiento muy puntual de los preparativos de los distintos festejos previstos para la entrada, de la construcción de complejos entremeses destinados a dignificar la presencia del monarca en la ciudad y de los diferentes elementos que los componían, pudiendo en gran medida reconstruirlos e interpretar su significado e intencionalidad, como así han hecho el citado Massip o María Milagros Cárcel Ortí y Juan Vicente García Marsilla por lo que respecta a los distintos entremeses que se prepararon para la entrada real de Fernando $\mathrm{I}^{17}$.

Sin duda, otras ceremonias de representación del poder real y con un sentido de comunicación política pública abierta pueden ser objeto de análisis y serán tenidos en cuenta en esta pesquisa, si bien en un segundo plano a causa del menor conocimiento documental o literario que tenemos de ellas a día de hoy. Es el caso de las distintas liturgias desarrolladas en torno al sitio de Balaguer durante el otoño de 1413 y la final entrada del rey victorioso en la ciudad rendida a él por el conde de Urgell, de las vistas desarrolladas en Morella entre Fernando I y el antipapa Benedicto XIII, en verano de 1414 o las negociaciones entabladas entre el rey de Aragón, el emperador Segismundo y el papa Luna en Perpiñán a final del año 1415, en relación con la problemática ligada a la resolución del cisma de la Iglesia. Los tres contextos son narrados con notable detalle en diferentes fuentes historiográficas, como la citada Crónica de Juan II de Castilla de Álvar García de Santa María, la Crónica de Juan II de Castilla de Fernán Pérez de Guzmán, las Recordanzas en tiempos del Papa Luna de Luis Panzán o los Anales de Aragón de Jerónimo Zurita $^{18}$. Sobre otras entradas reales y el ceremonial que en ellas se exhibió, como la realizada en Zaragoza por Fernando I a primeros de agosto de 1412 por desgracia, a día de hoy, no contamos con mayores noticias. Es de esperar que la información sobre estos momentos de representación simbólica del poder del rey Fernando I de Aragón pueda ampliarse en un futuro gracias al acceso a registros documentales del Archivo de la Corona de Aragón y a fuentes municipales.

\section{Usos representativos y conceptos para la exaltación del poder real: continuidad, reinterpretación e innovación}

11 La consideración de manera comparada de los momentos de expresión ceremonial arriba referidos ya puede ser objeto de evaluación a la hora de proponer respuestas sobre el sentido del discurso desarrollado al servicio del rey Fernando I de Aragón y su encaje dentro de un contexto de presumible legitimación tras Caspe y la rebelión del conde de Urgell. Las aportaciones historiográficas, incluidas las mías propias, que se han ocupado de trabajar esas entradas reales y las fiestas de la coronación, con la simbología en ellas manejada, lo permiten. En este sentido, podía entenderse todo el ceremonial y festejos de 
la coronación como un punto cumbre ciertamente excepcional en la exaltación de la figura de Fernando "el de Antequera" en su acceso a la dignidad real pero, en todo caso, éste no dejaba de encajar dentro de la evolución de un discurso y un lenguaje representativo conformado progresivamente en torno a la figura de este personaje desde su época como infante de Castilla, el cual se iría enriqueciendo para mayor afirmación de las cualidades y valores que adornaban a este príncipe durante la regencia de su sobrino Juan II de Castilla y al calor de la guerra contra Granada, entre 1406 y $1410^{19}$. Es por ello que el análisis detallado del ceremonial desplegado en los momentos de exaltación pública de la persona del nuevo rey de Aragón desde 1412 permite observar, como expondré a continuación, una lógica que se ordenó en un sentido triple. En primer lugar, mediante la adopción de fórmulas del ceremonial regio tradicional de los reyes de Aragón o el recurso sin alteraciones de significado a fórmulas representativas ya manejadas en los reinados de sus antecesores, tanto por iniciativa propia como a partir del concurso de instituciones y fuerzas sociales de la monarquía en actos de recepción o celebración de las personas reales. En segundo lugar, a través la reconducción de algunos de estos espectáculos ya conocidos en tiempos anteriores en servicio del discurso que pretendía escenificar el rey y su entorno. Para ello, se procedería al mantenimiento completo o de una parte sustancial de la forma de los elementos representativos mientras que el significado de los mismos o del conjunto era objeto de reinterpretación con el fin de ensalzar la figura del rey, de la reina o de sus hijos. En tercer y último lugar, la consecuencia lógica en la construcción de un nuevo significado para este tipo de espectáculos del ceremonial regio sería la elaboración de significantes también nuevos, con objetos integrados en la representación de nuevo cuño. Éstos, aunque pudieran integrarse en usos y tradiciones propias de la sociedad del momento en el Occidente bajomedieval, supondrían innovaciones en cuanto a la concepción y manifestación de la condición, dignidad y autoridad del rey, las cuales venían así a integrarse en el discurso de comunicación simbólica de la monarquía catalanoaragonesa a partir de las necesidades del nuevo monarca Fernando I de definición de su poder.

\subsection{Conceptos, imágenes simbólicas y espectáculos para un reinado: de la coronación a otros contextos ceremoniales}

12 Partiendo, entonces, de estas consideraciones, se puede afirmar, en primer lugar, que Fernando y su entorno no dejaron de adaptarse al ceremonial cortesano de Aragón, Así, el ceremonial de la coronación de Fernando y su esposa Leonor se adecuó de forma estricta a las ordinacions para tal efecto dispuestas por Pedro IV el Ceremonioso ${ }^{20}$. No en vano, y de acuerdo con ellas, Fernando veló armas en la noche víspera de su coronación en el sitial preparado al efecto sobre un gran tablado en el crucero de la Seo de Zaragoza ${ }^{21}$. Del mismo modo, esa noche de vísperas el rey vistió parcialmente ropajes blancos ${ }^{22}$, los cuales, el domingo 11 de febrero, para la ceremonia de ese día, una vez procedió a armarse él mismo caballero, cambió por otros en los que predominó claramente el blanco con detalles y borduras carmesíes, doradas y con amplia presencia de aljófar y otra pedrería en las calzas, zapatos, hábito, cordón, casulla, túnica y dalmática ${ }^{23}$. De esta guisa fue ungido por el obispo de Huesca para posteriormente tomar directamente del altar la corona, el cetro y el orbe en él depositados procesionalmente por sus hijos Alfonso, Juan y Enrique, respectivamente, para ceñirla en su cabeza y portarlos sin intermediación alguna $^{24}$. Del mismo modo, Leonor también veló el martes 13 para ser ungida y coronada 
el miércoles 14 de febrero, unos días después de la coronación de su esposo, con arreglo a los dispuesto en las ordinacions, exhibiendo vestiduras blancas diferentes en ambas jornadas, pronunciando las palabras contenidas en tales ordenanzas, ungida por el obispo de Huesca y ceñida la corona por su propio marido Fernando ${ }^{25}$.

Por otra parte, como ya he señalado, también se aprovecharon y adaptaron determinados elementos representativos ya previamente conocidos dentro de los espectáculos asociados a su coronación y sus entradas reales. Así puede deducirse de algunas partes de los entremeses que se preparaban para la entrada en Valencia del rey desde 1413, enviados e integrados en el llamado "entremés del Cisma" y en el de "de la Jarra de Santa María" en el banquete de la coronación del rey Fernando ${ }^{26}$. Algunos fragmentos de los cielos que aparecen en el "entremés de mestre Vicent" y del entremés de la "Divisa del senoyr rei" en Valencia, como las nubes o la torre, fueron utilizados en los espectáculos de Zaragoza $^{27}$. También ese fue el caso de los ángeles presentes en los cielos móviles preparados para el "entremés del Cisma" ${ }^{28}$. Mientras, se pidieron a Barcelona expresamente tres entremeses completos o las figuras animales principales de ellos, llamados "[...] lo Drach e l'Àguila e lo Basilisç" conocidos a partir de su presencia en la entrada real en dicha ciudad por el rey Fernando y que pueden rastrearse en la entrada real de Martín I en Barcelona, además de, luego, en la entrada real de Alfonso V en 1423 y en las festividades de Corpus de la ciudad condal del siglo $\mathrm{XV}^{29}$, para componer el águila y el grifo que se usarían en el entremés final del banquete, igual que las siete cabezas de demonio que se utilizaron en el "entremés del Cisma" para los Siete Pecados Capitales que se opusieron a las Siete Virtudes ${ }^{30}$.

En las situaciones citadas nos encontraríamos más bien con el aprovechamiento de determinados elementos escénicos pertenecientes a otros entremeses para su integración en nuevos espectáculos al servicio de una nueva significación conjunta, sobre la que luego se podrá volver. No puede compararse, en cualquier caso, el manejo de piezas de utilería que servían para construir las escenografías o caracterizar a algunos de los personajes más secundarios con la integración de figuras con valor simbólico y protagonismo más claro en el discurso del espectáculo evidente, como es el caso del águila y el grifo arriba citados. Ambos animales aparecían combatiéndose en el "entremés de la Jarra de Santa María", y que remitían directamente a la monarquía y a su autoridad espiritual y temporal, en una lectura celeste, en el caso del águila, mientras que la interpretación del grifo se podía hacer, dentro del entremés, en su carácter de bestia sobrenatural ligada al castigo del pecado cuyo combate reflejaba una acción de evidente sentido heroico dentro de la ética caballeresca ${ }^{31}$. Cabe, sin embargo, citar que también se dieron situaciones en que algunos de los entremeses ya representados en espectáculos de coronación o entrada regia en momentos anteriores en la Corona de Aragón fueron adoptados sin variación. Es muy representativa de esta adopción de espectáculos exitosos ya manejados en otros festejos la del entremés del triunfo de la Muerte. Escenificado en la entrada real de Martín I en Barcelona en 1397 y luego en la de Fernando I en esta misma ciudad 1412, fue solicitado por el rey para su inclusión, por dos veces, entre los entremeses de los banquetes en el palacio de la Aljafería que sucedieron a las coronaciones de los reyes Fernando y Leonor ${ }^{32}$. En este caso, la integración desde el ceremonial cívico al ceremonial monárquico de un tema de sentido alegórico y contenido moralizante por otro lado muy popular en la época no representaba mayor problema, al no generar ningún conflicto interpretativo en el conjunto del discurso propagandístico del rey. 
15 En cualquier caso, es francamente relevante que los entremeses del "Cisma" y de la "Jarra de Santa María" de la coronación fueron el resultado de un rechazo claro por parte del rey Fernando y su entorno al espectáculo original en que iban a basarse, pues se consideró inadecuado el sentido de la escena en él representado. Así parece deducirse por el enorme parecido entre uno de los entremeses que preparaba el consell de Valencia para la entrada real de Fernando I desde 1413, el de la "Divisa del senoyr rei", en el que luego me detendré, y otro entremés que se estaba diseñando para las fiestas de la coronación en Zaragoza, en el que había de aparecer la Virgen María y diversos ángeles para servir al rey en su mesa. Finalmente, el monarca ordenó que tal escena no se incluyera en los fastos del banquete al entender que esta imagen era poco digna para la ocasión ${ }^{33}$. La interpretación de Francesc Massip de la carta dirigida al baile general de Valencia relativa a este asunto vendría a confirmar lo que otras evidencias ya señaladas apuntaban: el origen valenciano de una gran parte de los elementos escénicos incluidos en estos dos entremeses de la coronación ${ }^{34}$. Sin embargo, a lo que se procedió fue a una completa restructuración de aquella escena. De ese modo, en ninguno de los espectáculos del banquete del 11 de febrero aparecía la Virgen María y sendos ángeles se presentaban ante el rey como mensajeros, uno en el "entremés del Cisma", otro al inicio del de la "Jarra de Santa María" expresamente como enviado de la Virgen, anunciándole ambos cómo había sido elegido por Dios y por María para el ejercicio de la potestad real y el desempeño de las misiones a ellas vinculadas: el liderazgo unido de sus reinos y súbditos y la resolución del cisma de la Iglesia en favor del legítimo pontificado del papa Luna ${ }^{35}$. El resultado eliminaba cualquier equívoco respecto una posible imagen utilitaria de la intermediación divina por parte del rey, manifestándose con cuidado la subordinación de Fernando a su designio por Dios, protegido por su Madre, para ostentar la corona de los reinos de Aragón.

16 Sin embargo, como ya decía, la integración de elementos simbólicos que podían ligarse con el discurso de exaltación de las virtudes y cualidades personales de la persona del rey Fernando, elaborado al menos desde 1403 fue especialmente relevante. En él confluían elementos más o menos originales generados en el entorno de Fernando desde sus años como infante de Castilla pero también otros que remitían a formas de la sacralización de la monarquía y de las personas regias en Castilla desde, al menos, los tiempos de Alfonso XI, si no anteriormente: la elección providencial de Fernando, manifestada a través de la especial protección prestada por la Virgen María y la devoción a ella, la promoción de los valores de la caballería y la incidencia en el liderazgo cruzado en la guerra contra los musulmanes para la "recuperación de España"36. Articulados todos estos principios alrededor de la orden caballeresca de la Jarra y el Grifo, fundada por el infante Fernando el 15 de agosto de 1403, como vehículos de la devoción mariana y la promoción del ideal caballeresco y príncipe en torno a Fernando, su presencia en el ceremonial real de éste a partir de su acceso al trono de Aragón resultó más que destacada. No podía ser de otro modo, pues tal expresión de la virtud y cualidades del príncipe se convertía en la mejor manifestación de la elección providencial que se habría hecho en Fernando para acometer las distintas empresas desarrolladas en su vida $\mathrm{y}$, al fin, ascender a la máxima dignidad regia en Aragón.

17 No es posible ahora extenderse en un análisis completo de todos los elementos a considerar en este sentido en el conjunto de las ceremonias de representación pública de las personas reales en el reinado de Fernando I. En todo caso, sí querría atender a algunos aspectos de especial relevancia ligados a los citados festejos de la coronación de Zaragoza y las entradas reales que vengo analizando, comenzando por subrayar cómo la jarra con 
las azucenas de la Virgen, el grifo y la banda blanca, símbolos de dicha orden de caballería, aparecieron con profusión durante las fiestas de la coronación.

Así, es cierto que el recurso a vestiduras blancas por el rey estaba estipulado en las ordenaciones de esta ceremonia, pero también entroncaba con el uso representativo de este color en las celebraciones de la hermandad caballeresca fundada y liderada por Fernando ${ }^{37}$. Las jarras también aparecían adornando el sitial del rey en la ceremonia que precedió a la vela de armas del rey en la Seo de Zaragoza el 10 de febrero, utilizado también en la misa en la capilla de Lope de Luna de la catedral que precedió el domingo 11 a la toma de caballería del rey y su posterior coronación ${ }^{38}$. También las jarras fueron portadas en sus vestiduras el día de ella, tal y como se ha señalado, e igualmente el rey cabalgó en su desfile solemne, de la Aljafería a la Seo y de la Seo a la Aljafería los días 10 y 11 antes y después de ser coronado, respectivamente, sobre un caballo con gualdrapa "[...] del mesmo paño que sus vestidos [...]", lo que presumiblemente remite, más que a que fueran blancas, a que lucían las armas reales ${ }^{39}$.

Mientras, en el "entremés de la Jarra de Santa María", ya nombrado y que sucedía al del "Cisma" en el final del banquete de la coronación del rey, los aspectos providenciales marianos, de virtud caballeresca y liderazgo guerrero asociados a Fernando como rey de Aragón pasaron a primer plano. En él, un niño ataviado con ropajes con las armas reales de Aragón y blandiendo una espada, salía de una jarra de azucenas de plata depositada en el centro de un castillo para derrotar al grifo que, acompañado por "moros alarbes", lo atacaba, tratando de vencer a sus defensores: seis doncellas y un águila dorada, aportada como se vio por el consell de Barcelona, a la que se añadió corona y, al cuello, el collar de la orden de la Jarra y el Grifo ${ }^{40}$. Las imágenes alegóricas del rey Fernando, son tremendamente expresivas: como protegido por la Virgen y enviado por Dios, defendiendo a su nuevo reino y a la propia dignidad real frente al Mal, representado por el grifo en su faceta de animal bestial acompañado por esos "moros", los cuales fácilmente reflejan a los paganos contra los que el infante, al frente de la hermandad de la Jarra y el Grifo, según rezaban sus estatutos, se comprometía a luchar en defensa de la iglesia, los pobres y los huérfanos ${ }^{41}$. Esta manifestación providencial de la elección del rey Fernando ya había sido presentada previamente durante el banquete. Así, en la representación primera de los "círculos del Paraíso" que iniciaba el banquete y su propia recepción, los cielos se hallaban rematados por dos niños, uno de los cuales coronaba al otro "[...] a remembrança de quando Dios coronó a la Virgen [...]”, lo cual podría evocar a su vez la propia coronación del rey Fernando, fruto último de la voluntad divina y que de algún modo se sancionaba con esa semejanza a la Coronación de la Virgen ${ }^{42}$. Mucho más evidente resultaba, en cualquier caso, que en el final del "entremés del Cisma" apareciera un ángel ante la mesa del rey, bajando de los cielos escenificados y entregándole, como embajador de la Virgen, una jarra dorada con azucenas como su señal "[...] que por siempre truxesse en su conquista [...]", designándole, en un ilustrativo gesto legitimador, como su predilecto para las empresas que hubiera de acometer ${ }^{43}$. Esos proyectos, a razón del desarrollo de los espectáculos del banquete, apuntaban hacia el justo gobierno de sus reinos, la resolución del cisma en favor de Benedicto XIII y, de un modo más implícito, la continuación de la guerra contra los musulmanes y su expulsión de suelo hispano como máxima expresión de su liderazgo como príncipe y caballero cristiano, que se evocaba en el combate contra el grifo y los "moros"

Este tipo de imágenes conceptos que vinculaban a Fernando I de Aragón con su elección providencial quedo reflejado en las habituales prácticas devocionales marianas y de 
hermandad caballeresca que durante todo su reinado giraron alrededor de la orden de la Jarra y el Grifo. Buen ejemplo de ello puede apreciarse en la continuidad en la celebración de la fiesta de la Asunción, ligada a citada orden desde su fundación en 1403 como festejo mayor de la hermandad ${ }^{45}$, dentro de las solemnidades periódicas de la corte aragonesa, como se ha podido documentar en las ocasiones del sitio de Balaguer en 1413 o de las vistas en Morella con Benedicto XIII en $1414^{46}$. Otro tanto puede decirse la difusión de la imagen del rey tejida en torno a la divisa caballeresca de la Jarra y el Grifo y el propio fomento de esta corporación como orden propia de la monarquía aragonesa, dejando de lado órdenes y divisas fundadas por sus antecesores como la de Sant Jordi d'Alfama, de Pedro IV, las divisas del Cinyell, del Águila y de la Corona Doble, de Juan I o aun la divisa de la Lleoparda y las empresas de la Corretja y de la Garrotera, de Martín I ${ }^{47}$.

La falta de evidencias que muestren que alguna de estas órdenes o divisas de sus antecesores fuera adoptada y mantenida por Fernando I contrasta con el esfuerzo de promoción de la Jarra y el Grifo, no sólo a partir de la exhibición pública dentro del ceremonial de distintos actos representativos, como estamos viendo, sino también mediante su profusa concesión entre los criados de su casa, los súbditos de sus reinos y aun caballeros y monarcas de otros lugares de la Cristiandad. En este sentido pueden ser ilustrativos dos ejemplos. Por un lado, la investidura de 80 caballeros con la divisa de la Jarra y el Grifo tras la misa solemne que sucedió a la capitulación y entrada en Balaguer el 5 de noviembre de $1413^{48}$. La toma de Balaguer al conde de Urgell, como un hecho de armas extraordinario que, igual que otras ceremonias de excepcional lustre político y simbólico, podía ser escenario para las no demasiado habituales investiduras caballerescas bajomedievales, fue aprovechada para la extensión de toda una serie de lazos de interdependencia personales entre los fieles del rey y hacia él mismo a través de su integración dentro de la hermandad por él liderada. Por otro lado, merece la pena traer a colación el intercambio entre Fernando I y el emperador Segismundo del emblema de la Jarra por el de la Sociedad del Dragón del emperador en el contexto de sus entrevistas en Perpiñán a final de 1415 para la búsqueda de acuerdos en la liquidación del cisma de la Iglesia junto con el antipapa Benedicto XIII ${ }^{49}$. Este acto de amistad en torno a ideales de caballería, en pos del reforzamiento de los tratos diplomáticos entre ambos, quedó sellado con más fuerza a partir del envío de la embajada de Felip de Malla en diciembre de ese año a Aviñón, a lo largo de la cual impuso la divisa de la orden del rey de Aragón al emperador Segismundo, al conde palatino de Hungría, Nicolás Garai el joven, el polaco Luis II, duque de Brieg, mossen Steve, que portaba ceremonialmente la espada del emperador, y otros seis caballeros más. A cuenta de ello, solicitó Segismundo el derecho para poder otorgar el emblema de la Jarra a otros 30 caballeros, despachando sus embajadores al rey de Aragón en 1416 para que impusiese a Fernando y a sus hijos los infantes Alfonso y Pedro el emblema de la Societas Draconistrarum del emperador, en tanto rey de Hungría ${ }^{50}$.

Atendiendo a lo expuesto, el elemento de virtud y liderazgo caballeresco ostentado por el rey Fernando I de Aragón se manifestó como de especial importancia a la hora de construir la imagen externa del monarca que fue presentada en diversos actos con fuerte contenido ceremonial de mayor o menor publicidad ante los naturales de sus reinos y dignatarios y príncipes extranjeros. La orden de la Jarra y el Grifo, en la medida en que escenificaba la relación especial establecida entre Fernando "el de Antequera" y la Providencia a través de la devoción y protección de la Virgen María, resultó crucial en ese sentido aunque no fue la única muestra de ese afán por evidenciar la condición ideal de 
caballero del rey. La propia coronación en Zaragoza vuelve a ofrecernos evidencias de enorme peso al respecto, al ser la vela de armas y toma de caballería por parte de Fernando los episodios previos a la propia unción y coronación y, de hecho, venir a manifestar, a través del ejercicio de la investidura caballeresca, la propia superioridad de la dignidad real y de su titular sobre sus reinos ${ }^{51}$.

Ya de por sí la vela de armas del sábado 10 de febrero planteaba esta situación, al menos en dos sentidos. En primer lugar, porque no sólo el rey Fernando velaría armas esa noche, sino que también lo hicieron sus hijos Alfonso y Juan y los hijos del condestable de Castilla Ruy López Dávalos, Pedro y Beltrán, quienes recibirían la caballería el día de la coronación de manos del rey y de forma subordinada a la propia investidura del soberano ${ }^{52}$. En segundo lugar, porque por más que el rey aún hubiera de protagonizar su propia toma de caballería, eso no impidió que, en el salón de los Mármoles de la Aljafería, antes de partir para la catedral zaragozana, Fernando armara públicamente (“[...] mostrándose a las gentes de muchas partes que ende estaban [...]") a seis caballeros ${ }^{53}$.

Según estos indicios, la potestad monárquica parecía llevar implícita la capacidad para conferir el rango de caballeros a otras personas sin ser condición necesaria entre sus titulares el haber recibido una investidura formal como tales. Este hecho de algún modo también quedó expresado en la medida en que los infantes Alfonso y Juan, tras la coronación de su padre, no fueron sometidos a ninguno de los rituales propios de la toma de caballería - ceñirles la espada a la cintura, espaldarazo o cachetada, recepción de los toques de espada sobre los hombros - sino que simplemente fueron investidos como príncipe de Gerona y como señor de Lara, respectivamente, por su padre, siéndoles impuestos chapeletes y mantos, además de una verga de oro para el infante primogénito como príncipe y heredero ${ }^{54}$. Más evidente a la hora de mostrar la superioridad que correspondía a la persona regia en relación con esta atribución resulta que, en efecto, Fernando tomó caballería por su propia mano: una vez fue bendecida la espada sobre el altar por el obispo de Huesca, él mismo la ciño para después darse la cachetada en la mejilla y blandir tres veces la espada, tras lo cual la desciñó y puso sobre el altar, dejándose poner las espuelas doradas por el infante Enrique, maestre de Santiago, su hijo y por su primo el duque de Gandía ${ }^{55}$.

25 Las ordinacions de Pedro IV tipificaban la toma de caballería por la propia mano del rey, siguiéndose, pues, este modelo, si bien fue su padre Alfonso IV el primer monarca aragonés que sabemos que se armó a sí mismo caballero en la ceremonia de su coronación en $1328^{56}$. Con todo, tampoco puede dejarse de lado que, junto a la necesaria observancia en este punto del ritual tradicional de la Corona de Aragón, Fernando I también contaba con otro poderoso referente a la hora de establecer en torno a la caballería un vínculo privilegiado en la transmisión del poder de forma directa de Dios al rey: su propia herencia castellana, normalizada en la coronación de Alfonso XI en 1332, de autoinvestidura caballeresca del rey, practicada también por el propio padre de Fernando, Juan I, en $1379^{57}$. Ya se contase con una estatua articulada de Santiago Apóstol con el fin de dar el espaldarazo al rey, como se indica que ocurrió en la Crónica de Alfonso $\mathrm{XI}$, o no fuera así y Alfonso XI y Juan I procedieron a actuar por su propia mano ${ }^{58}$, las tomas de caballería de ambos reyes castellanoleoneses en su coronación venían a reafirmar la autonomía respecto a cualquier mediación clerical entre Dios y el rey para la transmisión de su poder. Tal hecho hundía sus raíces en la toma de armas de Fernando III en 1219 y en la posterior de Alfonso X, si bien en 1221 Jaime I de Aragón reprodujo la 
acción de tomar la espada del altar y ceñírsela él mismo y sus sucesores Pedro III y Alfonso III actuaron del mismo modo ${ }^{59}$.

Ambas tradiciones, catalanoaragonesa y castellanoleonesa, bien parecen confluir en la investidura de la coronación de Fernando I, afirmando a partir de dicho acto caballeresco la autoridad y legitimidad del rey, basada en esa concepción simbólica de comunicación directa del poder de Dios al monarca. Aquél, en todo caso, insistió en la explicitación de su relación directa y virtuosa con la Virgen, presente en el conjunto de las celebraciones de la coronación de febrero de 1414, enunciando, al vestir las ropas previstas para la vela de armas, cómo eligió camisa y paños con braguero con hebilletas y troperas, todo en blanco, "[...] a significança que dende en adelante que usasse de castidad, de la qual virtud el dicho señor rey es fama que siempre uso como devoto caballero de Sancta Maria [...]"60. Una vez más devoción, virtud personal y elección providencial mariana, ejes por otra parte de un modelo de religiosidad intensamente cultivado por el linaje real castellano desde, al menos, los inicios del siglo XIII y bien transmitido entre los primeros monarcas Trastámara en la segunda mitad del siglo XIV, a menudo con un perfil caballeresco evidente, vienen a reforzar los elementos ligados al ejercicio y liderazgo en el orden de caballería del discurso legitimador de Fernando $\mathrm{I}^{61}$.

No hay lugar en este momento a profundizar aquí en algunos otros aspectos que podrían resultar de mucho interés por lo que respecta al manejo de valores caballerescos al servicio de la imagen pública del rey Fernando. Torneos, justas y otros juegos de armas desplegados en los días de la coronación o en ceremonias de entrada real ofrecen un interesante campo de estudio por lo que respecta a su valor desde el punto de vista de la comunicación simbólica. Así resulta tanto por lo que respecta al manejo de determinados colores estereotipados en algunos de estos actos, por ejemplo en el caso de sobrevestas de torneo y de parada verdes y rojas por parte de los caballeros implicados en ellos ${ }^{62}$, como por lo que toca al diseño de nuevos espectáculos de combate, a razón de las evidencias que parecen evocar unos incipientes pasos de armas organizados durante las fiestas de la coronación los días 12, 13 y 19 de febrero ${ }^{63}$.

\subsection{Síntesis conceptual y representativa en la entrada real en Valencia}

Realizado este amplio recorrido por la confluencia de significados y significantes en la elaboración y representación de un lenguaje de representación del poder y legitimidad del rey Fernando I de Aragón, me parece interesante concluir a partir de un ejemplo, ya evocado, que permite contemplar el esfuerzo de integración, reinterpretación y creación simbólica al que procedió el entorno del soberano durante su reinado para aquel fin. Quiero por ello volver a insistir en los núcleos centrales del discurso propagandístico generado en torno al monarca en los festejos supervisados por el consell de Valencia para la entrada real de éste, su esposa y su hijo Alfonso en dicha ciudad. Justamente, tales fastos, que llevaban preparándose desde 1413 y sólo pudieron llevarse a efecto entre el final de 1414 y el inicio de 1415, permiten reconocer un interesante proceso de interlocución entre la Corte real y las autoridades urbanas para la organización de un recibimiento que, postergado durante prácticamente dos años, integró con gran centralidad y expresividad los dos ejes de representación pública de la persona y el poder del rey Fernando: la exaltación de sus virtudes de cara a su ejercicio como monarca y su 
elección providencial para tal fin, conectada con la devoción mariana sostenida en torno a la orden de la Jarra y el Grifo.

No en vano, el primero de los cinco entremeses de la entrada recibió el nombre de la “ Divisa del senyor Rei", constando de un dispositivo ciertamente espectacular que formado por dos carros diferentes en los que mostraban dos escenas complementarias: el Verger, un suerte de hortus conclusus donde aparecía la Virgen María, rodeada por las jarras de azucenas y acompañada de un grifo, y la "Torre", a su vez compuesto por dos estructuras, una en forma de cielo, de donde partía un ángel enviado por la Virgen y que, mediante un curioso mecanismo a modo de nube, llegaba hasta la segunda, que semejaba una torre, en la que la figura alegórica de Fernando mostrado como infante esperaba en un asiento en lo alto de una torre a recibir el don de la Virgen ${ }^{64}$. Así, la imagen de la elección divina de Fernando de Castilla, como condición previa a la exposición de cualquiera de sus cualidades y como primer argumento de la superioridad de su persona para el ejercicio del poder soberano quedaba claramente de manifiesto.

Acto seguido, dos entremeses reafirmaban esta idea, evidenciando también esas virtudes y cualidades del monarca y de su estirpe ante sus súbditos, como apoyo a mejor legitimar su ejercicio del poder real. Para ello, eso sí, se procedió a exhibir referencias iconográficas y simbólicas novedosas, aunque bien integradas en el horizonte cultural de la época. Por un lado, un complejo entremés con dos carros, nombrado les set cadires (las siete sillas, sitiales), debía reflejar, en el primero, la rueda de los "siete planetas" precopernicanos (Sol, Luna, Mercurio, Venus, Marte, Saturno, Júpiter) girando alrededor de la Tierra, mientras que el segundo mostraba a los siete hijos del rey Fernando (Alfonso, Juan, Enrique, Sancho, Pedro, María y Leonor) en otra rueda alrededor de su padre ${ }^{65}$. Tras este entremés, ya el tercero de la entrada valenciana mostraba un tema de enorme popularidad y contenido moral en el imaginario tardomedieval: las edades del hombre y la rueda de la Fortuna. Distribuido en dos carros, debió de ser especialmente espectacular en sus dimensiones y formas, representándose en el primero una gran rueda móvil de gran complejidad mecánica, con las edades, en número de siete personajes, desde la niñez hasta la misma muerte en forma de cadáver en la sepultura, quedando en el centro un figurante que accionaba la rueda y que representaba también a la Fortuna. Mientras, el segundo carro reflejaba la Creación, con Dios sentado en el centro y, a su alrededor toda suerte de plantas y de animales ${ }^{66}$.

31 La integración de la monarquía y del mismo rey en el orden universal emanado de Dios es clara. En torno a la simbología del número siete, se articulan en escala la centralidad de Dios sobre la Creación, de la Tierra sobre el conjunto del Universo y el destino inevitable de la naturaleza humana pero también la centralidad del rey Fernando, del que emana su prolífica estirpe. La legitimidad del monarca, señalado por la Divinidad, y rodeado por sus siete hijos igualmente refleja idealmente ese orden perfecto que adornaría a la monarquía de Aragón en su titular y en sus descendientes ${ }^{67}$.

Resulta difícil no encontrar la conexión entre el simbolismo del carro de "los siete hijos del rey" y un poema compuesto por el castellano fray Diego de Valencia en los años anteriores al ascenso de Fernando de Antequera al trono de Aragón, en el cual los hijos de los infantes Fernando y Leonor son celebrados por sus virtudes, emanadas de sus padres de sangre real, plenos a su vez de virtudes por voluntad de Dios para los mayores logros. La asimilación con los siete planetas se encuentra por primera vez en esta composición, retomada para la entrada en Valencia, del mismo modo que la formulación de una estirpe 
fructífera, asimilada a plantas que provienen de la mejor raíz, sus padres, protegidos por Dios, para dar los mejores frutos en un provenir.

"Syete planetas rreales

vy salir de dos raíces

poderosas e felices

todas siete naturales;

e las plantas era tales,

segunt fue el mi avisso,

que manauan del paraíso

de dos fuentes perenales.

E la vna se desía

flor de nardo preçiosa,

e la otra abundossa

por do el balssamo corria;

estas fuentes que veya

eran criadas de Dios,

por vertud d'amas y dos

vna verga se regia.

[...]

Dios del çielo radiante

con las sus manos redichas

estas plantas sobredichas

bendiga muy de talante;

porque vea el Infante

e la su madre otrosy,

muy grant goso desde aquí

por los ver yr delante." ${ }^{68}$

A razón de lo expuesto sobre el "entremés de les set cadires" y el de "les set edats de l'home", la armonía de la imagen de la monarquía encarnada por Fernando I de Aragón no dejaba lugar a discusión. Del mismo modo, se mostraba la garantía de su continuidad y supervivencia en el futuro a partir de cada uno de esos "syete planetas rreales", ahuyentando el riesgo del desorden que significaría un nuevo interregno provocado por la falta de un heredero para el trono. La lógica de la proclamación de Caspe quedaba escenificada con toda viveza, de suerte que los espectadores pudieran sentirse partícipes del orden divino en el que ellos mismos giraban como súbditos en torno a una monarquía instituida a imagen y semejanza de la Creación sobre la base de la elección de su titular, Fernando "el de Antequera" por Dios y de la protección directa de la Virgen María.

\section{Conclusiones. Representar la legitimidad: ¿qué legitimidad?}

Hasta aquí llega este recorrido en torno al lenguaje simbólico desplegado por el rey Fernando I de Aragón en toda una serie distintas ceremonias de marcada dimensión pública desarrolladas al servicio de la legitimación de su ascenso al trono y de su ostentación de la dignidad real. El análisis del ceremonial y los festejos que enlucieron la solemne coronación de Fernando y Leonor en Zaragoza en febrero de 1414, además de algunas de sus entradas reales mejor conocidas y aún otros actos no exentos de contenido ceremonial desplegados en situaciones como el sitio de Balaguer en octubre de 1413 o las negociaciones con el emperador Segismundo en el tránsito entre los años 1415 y 1416, ha permitido comprobar cómo el discurso propagandístico elaborado en el entorno del rey 
Fernando destacó por su suntuosidad y riqueza representativa pero también por su desarrollada elaboración conceptual, su cuidada planificación y su espectacular puesta en escena.

Dicho lenguaje representativo y su significado fueron el resultado de conjugar la tradición ceremonial y representativa de la monarquía catalanoaragonesa y de las comunidades de los territorios de la Corona con propuestas y símbolos más ligados a la trayectoria personal de Fernando como infante y regente en Castilla o incluso a la propia andadura representativa de la autoridad y poder de la monarquía castellana. Al fin, como ya he podido señalar, la noción que tendió a prevalecer dentro de tal discurso fue la de la celebración de la elección providencial de Fernando, emanada directamente de la voluntad de Dios y reflejada a partir de la relación privilegiada de aquel con la Virgen María, para convertirse en rey. La consideración de sus virtudes personales para el ejercicio como gobernante y caballero cristiano y su espléndida exposición en ceremonias caballerescas, religiosas o cívicas, fiestas, representaciones escénicas o juegos de armas alcanzaban su más pleno sentido al ilustrar cómo el rey Fernando era el depositario de la voluntad de Dios para ceñir la corona de Aragón, aspectos todos ellos preferentemente articulados en torno a la hermandad caballeresca de la orden de la Jarra y el Grifo y sus distintivos.

Por otro lado, puede hacerse otra afirmación en cuanto al problema de la legitimación del derecho de Fernando "el de Antequera" al trono y su manejo en los distintos niveles de comunicación política que he podido estudiar en su reinado. No puede negarse que la presencia de las armas de Aragón y de Sicilia fue un continuo dentro de la exhibición pública del monarca durante todo su reinado. Si atendemos a las diferentes ceremonias estudiadas en estas páginas, los colores y composición de las armas reales ocuparon un lugar central en la representación de la persona del rey, tal y como se ha podido ver al describir vestiduras regias, gualdrapas de caballo, presencia de banderas y estandartes o personajes alegóricos ataviados con dichos colores en los festejos señalados de la coronación, de las entradas reales estudiadas o de la toma de Balaguer, entre otros ${ }^{69}$. Sin embargo, en ningún momento ha sido posible documentar la presencia de referencias de cualquier tipo dirigidas a mostrar públicamente que Fernando I descendía de forma legítima de la línea de sangre de los anteriores reyes de Aragón, sus antecesores, y que éste era el motivo principal de su derecho a ceñir la corona. Parece evidente que esto no fue considerado necesario, tal vez porque tras la proclamación de Caspe no había lugar a discutir la sucesión de Martín I por su sobrino Fernando de Castilla como su pariente más próximo y con derecho legítimo, sin duda perteneciente al casal d'Aragó. Al fin y al cabo, la decisión de los nueve compromisarios reunidos en Caspe no implicaba, en el plano teórico, elegir a un rey entre candidatos potenciales sino desvelar a una certeza: que el proclamado era quien siempre había ostentado los mejores y más directos vínculos de sangre para la sucesión. Partiendo de que todos los candidatos podían alegar lazos de consanguineidad que les hacían pertenecer a la casa reinante, una vez acatado Fernando mayoritariamente por los naturales de los territorios de la corona real de Aragón, la legitimidad en cuanto a la continuidad en él del linaje real no era cuestionable ${ }^{70}$. Dentro del discurso de la propaganda regia, al fin, con toda lógica, no se atendería a este aspecto de "legitimidad de origen", principio indiscutible que en el peor de los casos podía dar pie a las reivindicaciones de la, de todos modos, débil oposición urgelista, para insistir espléndidamente en las cuestiones señaladas de la elección providencial del príncipe y su virtud como gobernante y caballero cristiano. 
Más allá de lo aquí expresado, hay margen para continuar la vía iniciada a partir de esta investigación. Por un lado, tratando de enriquecer el conjunto de evidencias documentales relativas a la preparación y el desarrollo del discurso representativo de la monarquía durante el reinado de Fernando I en otras ceremonias de carácter público y marcado contenido simbólico ${ }^{71}$. Por otro lado, y regresando a lo referido por la preparación de los entremeses de la coronación y de la entrada real de Valencia de forma muy especial, por lo que toca el peso de la comunicación entre la monarquía y las instancias de poder dentro de la Corona de Aragón para la construcción del discurso en torno al poder regio y su representación pública en estos reinos a lo largo de toda la Baja Edad Media, al menos desde el siglo XIV. Difícilmente este proceso puede apreciarse como unidireccional sino más bien como el resultado de un diálogo negociado entre el rey y su entorno, de un lado, y las comunidades políticas de sus reinos para definir el lugar a ocupar por cada una de las partes en tal representación del poder.

Al fin, cabe preguntarnos si el seguimiento en esta línea de trabajo a partir del lenguaje simbólico generado en torno a Fernando I de Aragón, integrando elementos tradicionales de la monarquía catalanoaragonesa y otros reinterpretados o novedosos a partir de herencias diferentes, como la de Castilla, no podría llevar a verificar una base con continuidad en el futuro para la conformación de la representación simbólica de los reyes en Aragón en el siglo XV Ciertas apreciaciones consideraban que muchos de los principios conceptuales de manifestación del poder real asentados por el rey Fernando I sirvieron para el desarrollo del discurso y el ceremonial de sus sucesores, Alfonso V, Juan II y Fernando II el Católico. Esto puede valorarse particularmente a partir del papel asignado dentro dichos ceremonial cortesano y lenguaje representativo de estos reyes a la orden de la Jarra y el $\mathrm{Grifo}^{72}$. No en vano, la continuidad de la también conocida como "banda de Aragón" como orden de caballería de la monarquía hasta los inicios del siglo XVI está confirmada, conviviendo y posiblemente influyendo de forma directa en la sucesión de divisas personales adoptadas por Alfonso V (el mijo, el siti perillós, el libro abierto), Juan II (posiblemente el carro del triunfo de la Fortuna o de la Justicia) y Fernando el Católico (el yugo) ${ }^{73}$. La confirmación de la vitalidad de este rasgo, más vinculado al desarrollo de fórmulas de solidaridad aristocrática de tipo caballeresco y monárquico en época tardomedieval, bien podría colocarnos sobre la pista de la construcción de un marco conceptual y ceremonial propio para la monarquía de Aragón y Sicilia en el siglo XV. Un modelo de expresión del poder real con identidad propia pero abierto a captar influencias diversas y actuar como referente difusor de fórmulas de representación y comunicación política en el ámbito ibérico, del Mediterráneo occidental e incluso del conjunto de la Europa cristiana latina al final de la Edad Media.

\section{BIBLIOGRAFÍA}

Fuentes

CANCIONERO DE JUAN ALFONSO DE BAENA. Ed. José María Azáceta. Madrid: CSIC, 1966. 
DOCUMENTS DE LA PINTURA valenciana medieval i moderna. II: Llibre de l'Entrada del rei Martí. Ed. Joan Aliaga, Lluïsa Tolosa, Ximo Company. Valencia: Publicacions de la Universitat de València, 2007.

DOCUMENTS DE LA PINTURA valenciana medieval i moderna. IV: Llibre de l'entrada de Ferran d'Antequera . Ed. María Milagros Cárcel Ortí, Juan Vicente García Marsilla. Valencia: Universitat de València, 2013.

LES ENTRÉES RAYALES françaises de 1328-1515. Ed. Bernard Guenée, Françoise Lehoux. Paris: CNRS, 1968.

ORDINACIONS DE LA CASA i cort de Pere el Cerimoniós. Ed. Francisco M. Gimeno, Daniel Gozalbo, José Trench, Universitat de València, Valencia, 2009.

DORMER, Diego Iosef - Discvrsos varios de historia, con mvchas escritvras reales antigvas, y notas a algvnas dellas. Herederos de Diego Dormer: Zaragoza, 1683.

GARCÍA DE SANTA MARÍA, Álvar - Le parti inedite della "Crónica de Juan II" de Álvar García de Santa María. Ed. Donatella Ferro. Venecia: Consiglio Nazionale delle Richerche. Gruppo Studi d'Ispanistica, 1972.

PANZÁN, Luis - Recordanzas en tiempo del Papa Luna (1407-1435). Ed. Gregorio de Andrés. Madrid: Publicaciones de la Fundación Universitaria Española, 1987.

PÉREZ DE GUZMÁN, Fernán - Crónica del Serenísimo Príncipe Don Juan, segundo rey deste nombre en Castilla y en León. Ed. y notas de C. Rosell. Madrid: Ediciones Atlas, 1953.

ZURITA, Jerónimo -Anales de la Corona de Aragón, Libros X, XI y XII. Ed. Ángel Canellas López, ed. electrónica José Javier Iso, María Isabel Yagüe, Pilar Rivero. Zaragoza: Institución Fernando el Católico 1977 [Consult. 18 Ene. 2017]. Disponible en http://ifc.dpz.es/

Estudios

ANDRÉS DÍAZ, Rosana de - “Las entradas reales castellanas en los siglos XIV y XV”. En la España medieval 4 (1984), pp. 47-62.

BELLVESER, Ricard (coord.). Els valencians en el Compromís de Casp i en el Cisma d'Occident. Valencia: Institució Alfons el Magnànim, 2013.

BOULTON, D'Arcy J. D. - The Knights of the Crown: The Monarchical Orders of Knighthood in Later Medieval Europe 1325-1520. Woodbridge: Boydell Press, 2000.

BRESC, Henri - "L'empresa de la Correge et la conquète de la Sicilie: le royaume errant de Martin de Montblanc". Anuario de Estudios Medievales 23 (1993), pp. 197-220.

CARRASCO MANCHADO, Ana Isabel - Discurso político y propaganda en la Corte de los Reyes Católicos, (1474-1482). Madrid: [s. n.], 2000. Tesis doctoral.

CARRASCO MANCHADO, Ana Isabel - "Discurso político y propaganda en la corte de los Reyes Católicos: resultados de una primera investigación (1474-1482)”. En la España medieval 25 (2002), pp. 299-379.

CARRASCO MANCHADO, Ana Isabel - “La ceremonia de entrada real ¿un modelo castellano?”. in GONZÁLEZ JIMÉNEZ, Manuel, MONTES ROMERO-CAMACHO, Isabel (eds.) - La Península Ibérica entre el Mediterráneo y el Atlántico siglos XIII-XV. Cádiz-Sevilla: Diputación de Cádiz-Sociedad Española de Estudios Medievales, 2006, pp. 651-656.

CARRASCO MANCHADO, Ana Isabel - "Las entradas reales en la corona de Castilla: pacto y diálogo político en torno a la apropiación simbólica del espacio", in Le pouvoir symbolique en Occident (1300-1640). París: Publications de la Sorbonne-École française de Rome, 2013. 
CARRERO SANTAMARÍA, Eduardo - "Por las Huelgas los juglares. Alfonso XI de Compostela a Burgos, siguiendo el Libro de la Coronación de los Reyes de Castilla". Medievalia 15 (2012), pp. 143-157.

CORETH, Anna - "Orden von Stola und den Kanndeln und dem Greifen (Aragonesischer Kannenorden)”. Mitteilungen des Oesterreichischen Staatsarchivs 5 (1952), pp. 34-62.

DOMENGE I MESQUIDA, Joan - "Las joyas emblemáticas de Alfonso V". Anales de Historia del Arte 14-Número especial (2014), pp. 99-117.

DURÁN GUDIOL, Antonio - "El rito de la coronación del rey en Aragón”. Argensola: Revista de Ciencias Sociales del Instituto de Estudios Altoaragoneses 103 (1989), pp. 17-40.

ESPAÑOL BELTRÁN, Francesca - “Artistas y obras entre la Corona de Aragón y el reino de Francia”. in COSMÉN, María C., HERRÁEZ ORTEGA, María Victoria, PELLÓN GÓMEZ-CALCERRADA, María (coords.) - El intercambio artístico entre los reinos hispanos y las cortes europeas en la Baja Edad Media. León: Universidad de León, pp. 253-29.

FALCóN, Isabel (coord.) - XIX Congreso de Historia de la Corona de Aragón. 26-30 junio 2012. Caspe, Alcañiz y Zaragoza. El Compromiso de Caspe (1412), cambios dinásticos y Constitucionalismo en la Corona de Aragón. Zaragoza: Obra Social de Ibercaja, 2013.

FERNÁNDEZ DE CÓRDOVA MIRALLES, Álvaro - La corte de Isabel I. Ritos y ceremonias de una reina (1474-1504). Madrid: Dykinson, 2002.

FERNÁNDEZ DE CÓRDOVA MIRALLES, Álvaro - “Bajo el signo de Aljubarrota: la parábola emblemática y caballeresca de Juan I de Castilla (1379-1390)”. En la España medieval 37 (2014), pp. 9-84.

FERRER I MALLOL, Maria Teresa (coord.) - Martíl'Humà: el darrer rei de la dinastia de Barcelona (1396-1410). l'Interregne i el Compromís de Casp. Barcelona: Institut d'Estudis Catalans, 2015.

FERRER VALLS, Teresa - "La fiesta cívica en la ciudad de Valencia en el siglo XV”, in RODRÍGUEZ CUADROS, Evangelina (ed.) - Cultura y representación en la Edad Media. Alicante: Diputación Provincial de Alicante, Instituto Alicantino de Cultura Juan Gil-Albert, 1994, pp. 145-169.

FURIÓ, Antoni - “Un Debat inacabat. El Compromís de Casp a través de la historia”, in FERRER I MALLOL, Maria Teresa (coord.) - Martíl'Humà: el darrer rei de la dinastia de Barcelona (1396-1410). l'Interregne i el Compromís de Casp. Barcelona: Institut d'Estudis Catalans, 2015, pp. 815-865. GONZÁLEZ SÁNCHEZ, Santiago - Fernando I, regente de Castilla y rey de Aragón (1407-1416). Gijón: Trea, 2012

HYE, Franz-Heinz von - "Testimonios sobre órdenes de caballería españolas en Austria y estados vecinos (Bohemia, Alemania, Suiza y Hungría)”. En la España medieval 16 (1993), pp. 169-187.

INFANTES DE MIGUEL, Víctor - Las danzas de la muerte. Génesis y desarrollo de un género medieval (siglos XIII-XVII). Salamanca: Universidad de Salamanca, 1997.

MACKAY, Angus - "Don Fernando de Antequera y la Virgen Santa María”. in Homenaje al profesor Juan Torres Fontes. Murcia: Universidad de Murcia, 1987, Vol. II, pp. 949-957.

MARTÍN, José-Luis - "Un Debat inacabat y el Compromiso de Caspe ¿una incorporación a España?”, Espacio, Tiempo y Forma. Serie III, Historia Medieval 13 (2000), pp. 161-176.

MARTÍNEZ LLORENTE, Félix - "Divisas y heráldica. Encuentros y desencuentros de dos realidades emblemáticas”. Emblemata. Revista Aragonesa de Emblemática 20-21 (2014-2015), pp. 171-199. 
MASSIP BONET, Francesc - "Imagen y espectáculo del poder real en la entronización de los Trastámara (1414)", in XV Congreso de la Corona de Aragón (El poder real en la Corona de Aragón (siglos XIV-XVI). Zaragoza: Gobierno de Aragón, 1996, Tomo I, Vol. 3, pp. 371-386.

MASSIP BONET, Francesc - La monarquía en escena. Teatro, fiesta y espectáculo del poder en los reinos ibéricos: de Jaume el Conquistador al Príncipe Carlos. Madrid: Consejería de las Artes, 2003.

MASSIP BONET, Francesc - "Pompa cívica y ceremonia regia en la Corona de Aragón a fines del Medievo". Cuadernos del Cemyr 17 (2009), pp. 191-219.

MASSIP BONET, Francesc - A cos de rei: festa cívica i espectacle del poder reial a la Corona d'Aragó. Tarragona: Cossetània, 2010.

MASSIP BONET, Francesc - "Huellas de Oriente en las representaciones macabras de la Europa medieval: el caso catalán”. Cuadernos del Cemyr 19 (2011), pp. 137-161.

MASSIP BONET, Francesc - "El mecenazgo regio en la Corona de Aragón". Cuadernos del Cemyr 20 (2012), pp. 55-92.

MASSIP BONET, Francesc - "L'entrada valenciana dels primers Trastàmares". Locus amoenus 12 (2013-2014), pp. 55-65.

METGE, Bernat - Lo somni. Ed. Stefano Cingolani. Barcelona: Barcino, 2006.

MORALES ARRIZABALAGA, Jesús - "La publicación de Fernando de Castilla como Rey de Aragón. El 'Compromiso de Caspe' de 1412 como cuestión de justicia”, in SESMA MUÑOZ, José Ángel (dir. científico) - La Corona de Aragón en el centro de su Historia 1410-1412, pp. 315-346.

MULRYNE, J. Ronnie, ALIVERTI, Maria Ines, TESTAVERDE, Anna-Maria (eds.) - Ceremonial entries in Early Modern Europe. The iconography of power. Aldershot: Ashgate Publishing Limited, 2015.

MUÑOZ GÓMEZ, Víctor - “De Medina del Campo a Zaragoza: un periplo por las devociones "políticas" de un príncipe castellano bajomedieval (el infante Fernando de Antequera, 1380-1416)". eHumanista. Journal of Iberian Studies 24 (2013), pp. 375-395.

MUÑOZ GÓMEZ, Víctor - "La guerra contra el Islam en el proyecto político de Fernando 'el de Antequera', infante de Castilla y rey de Aragón (1380-1416)”, in RíOS SALOMA, Martín Federico (ed.) - El mundo de los conquistadores. Ciudad de México-Madrid: Instituto de Investigaciones Históricas. Universidad Nacional Autónoma de México - Sílex Ediciones, 2015.

MUÑOZ GÓMEZ, Víctor - Corona, señoríos y redes clientelares en la Castilla bajomedieval (ss. XIV-XV). El estado señorial y la casa de Fernando de Antequera y Leonor de Alburquerque, infantes de Castilla y reyes de Aragón (1374-1435). Valladolid: [s. n.], 2016. Tesis doctoral.

MUÑOZ GÓMEZ, Víctor - Fernando "el de Antequera” y Leonor de Alburquerque (1374-1435). Sevilla: Editorial Universidad de Sevilla, 2016.

MUÑOZ GÓMEZ, Víctor - "Después de Caspe: ceremonias, símbolos y legitimación en el reinado de Fernando I de Aragón”. in XLIII Semana Internacional de Estudios Medievales de Estella 'El acceso al trono'. Pamplona: Gobierno de Navarra, 2017, pp. 371-385.

NADOT, Sébatien - Le Spectacle des joutes. Sport et courtoisie à la fin du Moyen Âge. Rennes: Presses Universitaires de Rennes, 2012.

NARBONA CÁRCELES, María -"¡Ay!... las divisas de Carlos de Evreux, Príncipe de Viana (1421-1461)". Príncipe de Viana Vol. 72, 253 (2011), pp. 357-374.

NARBONA CÁRCELES, María - "El contenido devocional de las divisas: el azafrán y la olla ardiente de la reina de Aragón (1416-1458)”. Emblemata. Revista Aragonesa de Emblemática 20-21 (2014-2015), pp. $435-452$ 
NAVARRO ESPINACH, Germán - "La historiografía moderna del Compromiso de Caspe", in SESMA MUÑOZ, José Ángel (dir. científico) - La Corona de Aragón en el centro de su Historia 1410-1412. El Interregno y el Compromiso de Caspe. Zaragoza y Alcañiz, 24, 25 y 26 de noviembre de 2010. Zaragoza: Gobierno de Aragón. Departamento de Educación, Universidad, Cultura y Deporte, 2011, pp. 41-60.

NIETO SORIA, José Manuel - Ceremonias de la realeza: propaganda y legitimación en la Castilla Trastámara. Madrid: Nerea, 1993.

NIETO SORIA, José Manuel - “La realeza”. in NIETO SORIA, José Manuel (coord.) - Orígenes de la Monarquía Hispánica: Propaganda y legitimación (ca. 1400-1520). Madrid: Dykinson, 1999, pp. 25-62.

NIETO SORIA, José Manuel - “Ceremonia y pompa para una monarquía: los Trastámara en Castilla”. Cuadernos del Cemyr 17 (2009), pp. 51-72.

ORCÁSTEGUI GROS, Carmen - "La coronación de los reyes de Aragón: evolución políticaideológica y ritual”, in Homenaje a Don Antonio Durán Gudiol. Huesca: Instituto de estudios Altoaragoneses, 1995, pp. 633-647.

PALACIOS MARTÍN, Bonifacio - La Coronación de los Reyes de Aragón (1204-1410). Aportación al estudio de las estructuras medievales. Valencia: Anubar, 1975.

PALACIOS MARTÍN, Bonifacio - "Investidura de armas de los reyes españoles en los siglos XII y XIII". Gladius. Vol. Especial. Actas del I Simposio Nacional "Las Armas en la Historia (siglos XXIV)" (1988), pp. 153-192.

PÉREZ MONZÓN, Olga - “Ceremonias regias en la Castilla medieval. A propósito del llamado Libro de la Coronación de los reyes de Castilla y Aragón”. Archivo Español de Arte LXXXIII, 332 (2010), pp. 317-334.

PORRO GIRARDI, Nelly R. - La investidura de armas en Castilla. Valladolid: Junta de Castilla y León, 1998.

RAMOS VICENT, María del Pilar - "Reafirmación del poder monárquico en Castilla: la coronación de Alfonso XI". Cuadernos de Historia Medieval 3 (1983), pp. 3-36.

RAUFAST CHICO, Miguel - “¿Negociar la entrada del rey?: La entrada real de Juan II en Barcelona”. Anuario de Estudios Medievales 36/1 (2006), pp. 295-333.

RAUFAST CHICO, Miguel - “¿Un mismo ceremonial para dos dinastías?: las entradas reales de Martín el Humano (1397) y Fernando I (1412) en Barcelona”. En la España medieval 30 (2007), pp. 91-129.

RIERA I SANS, Jaume - “Els heralds i les divises del rei Martí (1356-1410)”. Paratge 14 (2002), pp. 41-61.

RUBIO VELA, Agustín - "Urgelistas valencianos. Sobre la oposición a Fernando I de Trastámara”, Anuario de Estudios Medievales 33/1 (2003), pp. 191-261.

RUBIO VELA, Agustín - "Después de Caspe. El urgelismo y las oligarquías”, in SESMA MUÑOZ, José Ángel (dir. científico) - La Corona de Aragón en el centro de su Historia 1410-1412. El Interregno y el Compromiso de Caspe. Zaragoza y Alcañiz, 24, 25 y 26 de noviembre de 2010. Zaragoza: Gobierno de Aragón. Departamento de Educación, Universidad, Cultura y Deporte, 2011, pp. 265-291.

SABATÉ I CURULL, Flocel - Lo senyor rey és mort!, Actitud i cerimònies dels municipis catalans baix medievals davant la mort del monarca. Lleida: Universitat de Lleida, 1994.

SÁINZ DE LA MAZA LASOLI, Regina - La Orden de San Jorge de Alfama. Aproximación a su historia. Barcelona: CSIC, 1990. 
SALICRÚ I LLUCH, Roser - "La coronació de Ferran d'Antequera. L'organització y els preparatius de la festa". Anuario de Estudios Medievales 25/2 (1995), pp. 699-759, en concreto, pp. 699-707.

SALICRÚ I LLUCH, Roser - "Caballeros cristianos en el Occidente europeo e islámico". in HERBERS, Klaus, JASPERS, Nikolas - "Das kommt mir spanisch". Eigenes und Fremdes in den deutschspanischen Beziehungen des spaten Mittelalters. Münster: Lit Verlag, 2004, pp. 217-289.

SESMA MUÑOZ, José Ángel - El Interregno (1410-1412). Concordia y Compromiso político en la Corona de Aragón. Zaragoza: Institución Fernando el Católico, 2011.

SESMA MUÑOZ, José Ángel - (dir.) - La Corona de Aragón en el centro de su Historia 1410-1412. El Interregno y el Compromiso de Caspe. Zaragoza y Alcañiz, 24, 25 y 26 de noviembre de 2010. Zaragoza: Gobierno de Aragón. Departamento de Educación, Universidad, Cultura y Deporte, 2011.

SUÁREZ FERNÁNDEZ, Luis - Historia del reinado de Juan I de Castilla. Tomo I. Estudio. Madrid: Universidad Autónoma de Madrid, 1977.

TENENTI, Alberto (ed.) - Humana Fragilitas. I temi della morte in Europa tra Duecento e Settecento. Clusone: Ferrari editrice, 2000.

TORRES FONTES, Juan - “Don Fernando de Antequera y la romántica caballeresca”. Miscelánea Medieval Murciana 5 (1980), pp.83-120.

VENDRELL GALLOSTRA, Francisca - "Caballeros centroeuropeos en la Corte aragonesa". Miscellanea Barcinonensia Vol. X, XXVIII (1971), pp. 19-43.

VICENS VIVES, Jaume - Els Trastàmares (segle XV). Barcelona: Teide, 1956.

\section{NOTAS}

1. Para una aproximación general actualizada a las cuestiones de política internacional del reinado de Fernando I de Aragón y, más en concreto, al interregno, acceso al trono de Fernando I de Castilla y consolidación en él, baste aquí ceñirnos a la producción más actualizada, generada a partir de las conmemoraciones entre 2010 y 2012 de dichos acontecimientos: SESMA MUÑOZ, José Ángel - El Interregno (1410-1412). Concordia y Compromiso político en la Corona de Aragón. Zaragoza: Institución Fernando el Católico, 2011; SESMA MUÑOZ, José Ángel (dir. científico) - La Corona de Aragón en el centro de su Historia 1410-1412. El Interregno y el Compromiso de Caspe. Zaragoza y Alcañiz, 24, 25 y 26 de noviembre de 2010. Zaragoza: Gobierno de Aragón. Departamento de Educación, Universidad, Cultura y Deporte, 2011, en particular en este volumen, RUBIO VELA, Agustín - "Después de Caspe. El urgelismo y las oligarquías", pp. 265-291; GONZÁLEZ SÁNCHEZ, Santiago - Fernando I, regente de Castilla y rey de Aragón (1407-1416). Gijón: Trea, 2012, pp. 117-185; BELLVESER, Ricard (coord.) - Els valencians en el Compromís de Casp $i$ en el Cisma d'Occident. Valencia: Institució Alfons el Magnànim, 2013; FALCóN, Isabel (coord.) - XIX Congreso de Historia de la Corona de Aragón 26-30 junio 2012. Caspe, Alcañiz y Zaragoza. El Compromiso de Caspe (1412), cambios dinásticos y Constitucionalismo en la Corona de Aragón. Zaragoza: Obra Social de Ibercaja, 2013; FERRER I MALLOL, Maria Teresa (coord.) - Martí l'Humà: el darrer rei de la dinastia de Barcelona (1396-1410). l'Interregne i el Compromís de Casp. Barcelona: Institut d'Estudis Catalans, 2015; MUÑOZ GÓMEZ, Víctor - Fernando "el de Antequera" y Leonor de Alburquerque (1374-1435). Sevilla: Editorial Universidad de Sevilla, 2016, pp. 99-117.

2. Conviene aquí retrotraerse al debate de corte nacionalista entre posturas catalanistas y españolistas sobre la interpretación del compromiso de Caspe, del que uno de sus hitos más 
famosos es el célebre debate entre Ferrán Soldevila y Ramón Menéndez Pidal. Sin ánimo de remitir a un tema que ya he podido abordar en otros estudios, remito preferentemente a las valoraciones historiográficas, pertinentes y alejadas de partidismos nacionalistas de MARTíN, José-Luis - “Un Debat inacabat y el Compromiso de Caspe ¿una incorporación a España?”. Espacio, Tiempo y Forma. Serie III, Historia Medieval 13 (2000), pp. 161-176; NAVARRO ESPINACH, Germán "La historiografía moderna del Compromiso de Caspe", in SESMA MUÑOZ, José Ángel (dir. científico) - La Corona de Aragón en el centro de su Historia 1410-1412, pp. 41-60; FURIÓ, Antoni - "Un Debat inacabat. El Compromís de Casp a través de la historia”, in FERRER I MALLOL, Maria Teresa (coord.) - Martíl'Humà, pp. 815-865.

3. Bien representativos de estas dos posturas resultan los trabajos ya citados de, para la primera, SESMA MUÑOZ, José Ángel - El Interregno (1410-1412); y para la segunda, de FURIÓ, Antoni - "Un Debat inacabat". Tampoco conviene, en relación con las valoraciones de la resolución del interregno en términos fundamentales de interés político las aportaciones de José-Luis Martín ( FURIÓ, Antoni - "Un Debat inacabat) ni aún las anteriores de Jaume Vicens Vives (VICENS VIVES, Jaume - Els Trastàmares (segle XV). Barcelona: Teide, 1956, en especial pp. 99-102).

4. MUÑOZ GÓMEZ, Víctor - Corona, señoríos y redes clientelares en la Castilla bajomedieval (ss. XIV-XV). El estado señorial y la casa de Fernando de Antequera y Leonor de Alburquerque, infantes de Castilla y reyes de Aragón (1374-1435). Valladolid: [s. n.], 2016. Tesis doctoral (defendida en la Universidad de Valladolid bajo la dirección del profesor Pascual Martínez Sopena). En concreto, sobre el discurso propagandístico de Fernando "el de Antequera", en ese trabajo, pp. 607-647, o una versión revisada para su edición en MUÑOZ GÓMEZ, Víctor - Fernando “el de Antequera”, pp. 119-163.

5. MUÑOZ GÓMEZ, Víctor - "Después de Caspe: ceremonias, símbolos y legitimación en el reinado de Fernando I de Aragón”. in XLIII Semana Internacional de Estudios Medievales de Estella "El acceso al trono'. Pamplona: Gobierno de Navarra, 2017, pp. 371-385.

6. En relación con el ceremonial regio y el papel político de la representación del poder en las Coronas de Castilla y Aragón al final de la Edad Media, véanse, entre otros NIETO SORIA, José Manuel - Ceremonias de la realeza: propaganda y legitimación en la Castilla Trastámara. Madrid: Nerea, 1993; SABATÉ I CURULL, Flocel - Lo senyor rey és mort!, Actitud i cerimònies dels municipis catalans baix medievals davant la mort del monarca. Lleida: Universitat de Lleida, 1994; CARRASCO MANCHADO, Ana Isabel - Discurso político y propaganda en la Corte de los Reyes Católicos, (1474-1482). Madrid: [s. n.], 2000. Tesis doctoral (defendida en la Universidad Complutense de Madrid bajo la dirección del profesor José Manuel Nieto Soria); FERNÁNDEZ DE CóRDOVA MIRALLES, Álvaro - La corte de Isabel I. Ritos y ceremonias de una reina (1474-1504). Madrid: Dykinson, 2002; MASSIP BONET, Francesc - La monarquía en escena. Teatro, fiesta y espectáculo del poder en los reinos ibéricos: de Jaume el Conquistador al Príncipe Carlos. Madrid: Consejería de las Artes, 2003.

7. SALICRÚ I LLUCH, Roser - "La coronació de Ferran d'Antequera. L'organització y els preparatius de la festa". Anuario de Estudios Medievales, 25/2 (1995), pp. 699-759, en concreto pp. 699-707; MASSIP BONET, Francesc - "Imagen y espectáculo del poder real en la entronización de los Trastámara (1414)", in XV Congreso de la Corona de Aragón (El poder real en la Corona de Aragón (siglos XIV-XVI). Zaragoza: Gobierno de Aragón, 1996, Tomo I, Vol. 3, pp. 371-386; NIETO SORIA, José Manuel - "La realeza". in NIETO SORIA, José Manuel (coord.) - Orígenes de la Monarquía Hispánica: Propaganda y legitimación (ca. 1400-1520). Madrid: Dykinson, 1999, pp. 25-62, en concreto pp. 46-49; NIETO SORIA, José Manuel - "Ceremonia y pompa para una monarquía: los Trastámara en Castilla". Cuadernos del Cemyr 17 (2009), pp. 51-72, en concreto p. 56.

8. MACKAY, Angus - "Don Fernando de Antequera y la Virgen Santa María”. in Homenaje al profesor Juan Torres Fontes. Murcia: Universidad de Murcia, 1987, Vol. II, pp. 949-957.

9. SALICRÚ I LLUCH, Roser - "La coronació"; MASSIP BONET, Francesc - "Imagen y espectáculo"; MASSIP BONET, Francesc - A cos de rei: festa cívica i espectacle del poder reial a la Corona d'Aragó. Tarragona: Cossetània, 2010, en especial pp. 99-120; MASSIP BONET, Francesc - "El mecenazgo regio en la Corona de Aragón”. Cuadernos del Cemyr 20 (2012), pp. 55-92, en concreto pp. 58-66. 
10. SALICRÚ I LLUCH, Roser - “La coronació”, pp. 751-752. Volveré sobre ello más adelante. 11. SALICRÚ I LLUCH, Roser - "La coronació", pp. 752; MASSIP BONET, Francesc - "L'entrada valenciana dels primers Trastàmares". Locus amoenus 12 (2013-2014), pp. 55-65, en concreto pp. 58,64 .

12. GARCÍA DE SANTA MARÍA, Álvar - Le parti inedite della "Crónica de Juan II" de Álvar García de Santa María. Ed. Donatella Ferro. Venecia: Consiglio Nazionale delle Richerche. Gruppo Studi d'Ispanistica, 1972, pp. 97-130.

13. Sobre las entradas reales en el Occidente bajomedieval y en Castilla y Aragón, de un modo general, LES ENTRÉES ROYALES françaises de 1328-1515. Ed. Bernard Guenée, Françoise Lehoux. Paris: CNRS, 1968; ANDRÉS DÍAZ, Rosana de - "Las entradas reales castellanas en los siglos XIV y XV”. En la España medieval 4 (1984), pp. 47-62; NIETO SORIA, José Manuel - Ceremonias de la realeza, pp. 119-143; FERRER VALLS, Teresa - "La fiesta cívica en la ciudad de Valencia en el siglo XV", in RODRÍGUEZ CUADROS, Evangelina (ed.) - Cultura y representación en la Edad Media. Alicante: Diputación Provincial de Alicante, Instituto Alicantino de Cultura Juan Gil-Albert, 1994, pp. 145-169; CARRASCO MANCHADO, Ana Isabel - "Discurso político y propaganda en la corte de los Reyes Católicos: resultados de una primera investigación (1474-1482)”. En la España medieval 25 (2002), pp. 299-379, en concreto pp. 308-312, pp. 317-322, pp. 327-328, pp. 345-360; CARRASCO MANCHADO, Ana Isabel - "La ceremonia de entrada real ¿un modelo castellano?”. in GONZÁLEZ JIMÉNEZ, Manuel, MONTES ROMERO-CAMACHO, Isabel (eds.) - La Península Ibérica entre el Mediterráneo y el Atlántico siglos XIII-XV. Cádiz-Sevilla: Diputación de Cádiz-Sociedad Española de Estudios Medievales, 2006, pp. 651-656; RAUFAST CHICO, Miguel - “¿Negociar la entrada del rey?: La entrada real de Juan II en Barcelona". Anuario de Estudios Medievales 36/1 (2006), pp. 295-333; CARRASCO MANCHADO, Ana Isabel - "Las entradas reales en la corona de Castilla: pacto y diálogo político en torno a la apropiación simbólica del espacio", in Le pouvoir symbolique en Occident (1300-1640). París: Publications de la Sorbonne-École française de Rome, 2013; MULRYNE, J. Ronnie, ALIVERTI, Maria Ines, TESTAVERDE, Anna-Maria (eds.) - Ceremonial entries in Early Modern Europe. The iconography of power. Aldershot: Ashgate Publishing Limited, 2015.

14. RAUFAST CHICO, Miguel - “¿Un mismo ceremonial para dos dinastías?: las entradas reales de Martín el Humano (1397) y Fernando I (1412) en Barcelona”. En la España medieval 30 (2007), pp. 91-129.

15. MASSIP BONET, Francesc - "Pompa cívica y ceremonia regia en la Corona de Aragón a fines del Medievo". Cuadernos del Cemyr 17 (2009), pp. 191-219; MASSIP BONET, Francesc - "L'entrada valenciana".

16. DOCUMENTS DE LA PINTURA valenciana medieval i moderna. II: Llibre de l'Entrada del rei Martí. Ed. Joan Aliaga, Lluïsa Tolosa, Ximo Company. Valencia: Publicacions de la Universitat de València, 2007; DOCUMENTS DE LA PINTURA valenciana medieval i moderna. IV: Llibre de l'entrada de Ferran d'Antequera. Ed. María Milagros Cárcel Ortí, Juan Vicente García Marsilla. Valencia: Universitat de València, 2013.

17. MASSIP BONET, Francesc - "L'entrada valenciana"; Documents Llibre de l'entrada de Ferran d'Antequera, pp. 7-25, correspondientes al estudio introductorio de la edición.

18. PÉREZ DE GUZMÁN, Fernán - Crónica del Serenísimo Príncipe Don Juan, segundo rey deste nombre en Castilla y en León. Ed. y notas de C. Rosell. Madrid: Ediciones Atlas, 1953; PANZÁN, Luis Recordanzas en tiempo del Papa Luna (1407-1435). Ed. Gregorio de Andrés. Madrid: Publicaciones de la Fundación Universitaria Española, 1987; ZURITA, Jerónimo -Anales de la Corona de Aragón, Libros X, XI y XII. Ed. Ángel Canellas López, ed. electrónica José Javier Iso, María Isabel Yagüe, Pilar Rivero. Zaragoza: Institución Fernando el Católico 1977 [Consult. 18 Ene. 2017]. Disponible en http://ifc.dpz.es/.

19. MUÑOZ GÓMEZ, Víctor - Fernando "el de Antequera”, pp. 119-163. 
20. PALACIOS MARTÍN, Bonifacio - La Coronación de los Reyes de Aragón (1204-1410). Aportación al estudio de las estructuras medievales. Valencia: Anubar, 1975; ORCÁSTEGUI GROS, Carmen - "La coronación de los reyes de Aragón: evolución política-ideológica y ritual", in Homenaje a Don Antonio Durán Gudiol. Huesca: Instituto de estudios Altoaragoneses, 1995, pp. 633-647; ORDINACIONS DE LA CASA i cort de Pere el Cerimoniós. Ed. Francisco M. Gimeno, Daniel Gozalbo, José Trench (ed.), Universitat de València, Valencia, 2009.

21. GARCÍA DE SANTA MARÍA, Álvar - Le parti inedite, pp. 97-102, en especial pp. 99-101.

22. "El rey queriendo salir a los caballeros e nobles que le estaban esperando, desnudose las ropas que traia e vestiose camisa e paños de lino nuevos con braguero de sirgo e con feuilletas de plata blancas e sus troperas de sirgo blanco". El jubón, las calzas, la saya y el pellote que lució encima, no obstante, no portaban estos colores sino dorado y escarlata o carmesí, reflejando con ellos los de las armas reales de Aragón (GARCÍA DE SANTA MARÍA, Álvar - Le parti inedite, pp. 97-102, en especial pp. 99-102).

23. GARCÍA DE SANTA MARÍA, Álvar - Le parti inedite, pp. 103-104.

24. GARCÍA DE SANTA MARÍA, Álvar - Le parti inedite, pp. 104-107.

25. GARCÍA DE SANTA MARÍA, Álvar - Le parti inedite, pp. 122-125.

26. GARCÍA DE SANTA MARÍA, Álvar - Le parti inedite, pp. 113-120.

27. MASSIP BONET, Francesc - "L'entrada valenciana", pp. 57-58.

28. SALICRÚ I LLUCH, Roser - "La coronació”, “p. 753, ACA, C., reg. 2.403, f. 153 r., 1413, diciembre, 9, Lleida); MASSIP BONET, Francesc - A cos de rei, pp. 98-106.

29. METGE, Bernat - Lo somni. Ed. Stefano Cingolani. Barcelona: Barcino, 2006, p. 276; MASSIP BONET, Francesc - A cos de rei, pp. 45-72.

30. SALICRÚ I LLUCH, Roser - "La coronació", pp. 751-752; ACA, C., reg. 2.403, f. 149 r., 1413, diciembre, 2, Lleida; reg. 2.404, f. 85 v., 1413, diciembre, 4, Lleida).

31. MASSIP BONET, Francesc - A cos de rei, pp. 61, 64. No ha de olvidarse que el simbolismo del grifo, como el más poderoso de los animales de los bestiarios medievales, junto con el valor "negativo" que hemos referido, también podía evocar un perfil "positivo", integrando elementos celestes y terrestres, vinculados a la doble naturaleza de Cristo, la profética redención de los cristianos y su protección frente a los infieles (FERNÁNDEZ DE CÓRDOVA MIRALLES, Álvaro "Bajo el signo de Aljubarrota: la parábola emblemática y caballeresca de Juan I de Castilla (1379-1390)". En la España medieval, 37 (2014). pp. 9-84, en concreto pp. 33-46, 64-84; MUÑOZ GÓMEZ, Víctor - Fernando "el de Antequera", pp. 136-137.

32. GARCÍA DE SANTA MARÍA, Álvar - Le parti inedite, pp. 118, 126-127; MASSIP BONET, Francesc A cos de rei, pp. 74-85, 106-110. En relación a la temática de las danzas de la muerte y otras formas de espectáculos macabros, de forma general y con mayor atención a casos ibéricos, INFANTES DE MIGUEL, Víctor - Las danzas de la muerte. Génesis y desarrollo de un género medieval (siglos XIII-XVII). Salamanca: Universidad de Salamanca, 1997; TENENTI, Alberto (ed.) - Humana Fragilitas. I temi della morte in Europa tra Duecento e Settecento. Clusone: Ferrari editrice, 2000; MASSIP BONET, Francesc - "Huellas de Oriente en las representaciones macabras de la Europa medieval: el caso catalán". Cuadernos del Cemyr 19 (2011), pp. 137-161.

33. SALICRÚ I LLUCH, Roser - "La coronació", pp. 752; ACA, C., reg. 2.403, ff. 157 v.-158 r., 1413, diciembre, 15, Lleida.

34. MASSIP BONET, Francesc - "L'entrada valenciana", pp. 58, 64.

35. GARCÍA DE SANTA MARÍA, Álvar - Le parti inedite, pp. 115, 119; MUÑOZ GÓMEZ, Víctor Fernando "el de Antequera", pp. 160-161.

36. Remito sobre estas cuestiones, para su estudio más pormenorizado, a algunos trabajos recientes míos [MUÑOZ GÓMEZ, Víctor - "De Medina del Campo a Zaragoza: un periplo por las devociones "políticas" de un príncipe castellano bajomedieval (el infante Fernando de Antequera, 1380-1416)”. eHumanista. Journal of Iberian Studies 24 (2013), pp. 375-395; MUÑOZ GÓMEZ, Víctor "La guerra contra el Islam en el proyecto político de Fernando 'el de Antequera', infante de 
Castilla y rey de Aragón (1380-1416)", in RÍOS SALOMA, Martín Federico (ed.) - El mundo de los conquistadores. Ciudad de México-Madrid: Instituto de Investigaciones Históricas. Universidad Nacional Autónoma de México - Sílex Ediciones, 2015].

37. Así se estipulaba en las ordenanzas que regían esta orden de caballería, establecidas a la fundación de las mismas, en su tercer artículo, el uso de vestidos blancos para la celebración de la fiesta de la Asunción de la Virgen. Véase DORMER, Diego Iosef - Discvrsos varios de historia, con mvchas escritvras reales antigvas, y notas a algvnas dellas. Herederos de Diego Dormer: Zaragoza, 1683, pp. 188-197; TORRES FONTES, Juan - "Don Fernando de Antequera y la romántica caballeresca”. Miscelánea Medieval Murciana 5 (1980), pp.83-120, en concreto pp. 112-117; MUÑOZ GÓMEZ, Víctor - Fernando "el de Antequera", pp. 250-258.

38. GARCÍA DE SANTA MARÍA, Álvar - Le parti inedite, pp. 99-102). Se cita la “ [...] silla rica de las jarras, que estaba en el palacio de los Mármoles[...]”, en la que se sentó el rey Fernando en las investiduras caballerescas de varios de sus criados ese día 10 antes de su propia vela de armas en la Seo de Zaragoza (GARCÍA DE SANTA MARÍA, Álvar - Le parti inedite, p. 99). Puede que se trate de la misma "[...] silla que estaba cabe el pilar [del crucero de la catedral] la quale tenia a los quatro cantos, e cada cinco una jarrilla de Sancta Maria con sus lirios cubierta con un paño de azeituni villotado carmesin". (GARCÍA DE SANTA MARÍA, Álvar - Le parti inedite, p. 101) o tal vez de dos sitiales diferentes que, en cualquier caso, contaban con el mismo elemento decorativo y simbólico central, ligando al rey con la devoción y protección de la Virgen.

39. GARCÍA DE SANTA MARÍA, Álvar - Le parti inedite, pp. 109. La casulla y la dalmática del rey llevaba bordadas, junto a otro adornos de oro, aljófar y pedrería, las jarras de la Virgen (ver nota 23). En relación a esos ropajes reales con las armas de Aragón, ver nota 22.

40. GARCÍA DE SANTA MARÍA, Álvar - Le parti inedite, pp. 118-120.

41. MUÑOZ GÓMEZ, Víctor - Fernando "el de Antequera", pp. 154, 253, 257.

42. MUÑOZ GÓMEZ, Víctor - Fernando "el de Antequera”, p. 113. Así interpreta lo descrito con esas palabras precisas por García de Santa María, con muy probable acierto, MASSIP BONET, Francesc - A cos de rei, pp. 99-100.

43. GARCÍA DE SANTA MARÍA, Álvar - Le parti inedite, p. 119.

44. En relación a esas loas a la legitimidad del papa Luna en el solio pontificio que Fernando I de Aragón habría de sostener, manifestadas por las coplas pronunciadas por los dos ángeles mensajeros del "entremés del Cisma" y el de la "jarra de Santa María", amén del sentido caballeresco y de continuación de la "recuperación de España" en los espectáculos de la coronación, véase la nota 35. Igualmente, más específicamente en cuanto a la asociación de la persona de Fernando "el de Antequera" con el caudillaje de la guerra contra los musulmanes dentro de su discurso de legitimación del poder desde su época como infante de Castilla, enriquecido desde 1407 y presente en su política real como monarca de Aragón, MUÑOZ GÓMEZ, Víctor - "La guerra contra el Islam pp. 415-417 y ss.

45. MUÑOZ GÓMEZ, Víctor - "De Medina del Campo a Zaragoza", pp. 380-385; MUÑOZ GÓMEZ, Víctor - Fernando "el de Antequera", pp. 133-139.

46. ACA, Cancillería, reg. 2412 (Ferran I-Pecuniae 2. 1413-1416), fol. 41 r.: referencia al pago el día 16 de agosto de 1413 a los menestrales que intervinieron en la celebración de la festividad de la Virgen. Sobre la celebración en 1414 en Morella, J. ZURITA, Anales, libro XII, cap. XLI: pp. 248-249.

47. SÁINZ DE LA MAZA LASOLI, Regina - La Orden de San Jorge de Alfama. Aproximación a su historia. Barcelona: CSIC, 1990; BRESC, Henri - "L'empresa de la Correge et la conquète de la Sicilie: le royaume errant de Martin de Montblanc". Anuario de Estudios Medievales 23 (1993), pp. 197-220; RIERA I SANS, Jaume - "Els heralds i les divises del rei Martí (1356-1410)". Paratge 14 (2002), pp. 41-61; ESPAÑOL BELTRÁN, Francesca - "Artistas y obras entre la Corona de Aragón y el reino de Francia”. in COSMÉN, María C., HERRÁEZ ORTEGA, María Victoria, PELLÓN GÓMEZ-CALCERRADA, María (coords.) - El intercambio artístico entre los reinos hispanos y las cortes europeas en la Baja Edad Media. León: Universidad de León, pp. 253-294, en concreto pp. 270-274; MARTÍNEZ LLORENTE, 
Félix - "Divisas y heráldica. Encuentros y desencuentros de dos realidades emblemáticas". Emblemata. Revista Aragonesa de Emblemática 20-21 (2014-2015), pp. 171-199, en concreto pp. 180-181, pp. 184-186.

48. ZURITA, Jerónimo - Anales, Libro XII, cap. XXX, p. 234.

49. ZURITA, Jerónimo - Anales, cap. LIX, pp. 279-280.

50. La comisión de Fernando I a Felip de Malla para otorgar la divisa de la Jarra al conde palatina de Hungría se data a 20 de diciembre en Perpiñán, mientras que las dos cartas del teólogo embajador desde Aviñón son de los días 1 y 11 de enero de 1416 [VENDRELL GALLOSTRA, Francisca - "Caballeros centroeuropeos en la Corte aragonesa". Miscellanea Barcinonensia. Vol. X, no XXVIII (1971), pp. 19-43, en concreto pp. 29-35, 41-42].

51. GARCÍA DE SANTA MARÍA, Álvar - Le parti inedite, pp. 97-102.

52. Aunque se cita en la comitiva reunida en el palacio de la Aljafería también a los infantes Enrique, Sancho y Pedro y el cronista García de Santa María indica que los hijos del condestable “[...] venían a ser caballeros con los hijos del rey [...]", igualmente éste señala que cabalgaron junto al rey en dirección a la Seo "[...] don Alonso e don Joan sus fijos en otros dos caballos con coberturas de paño de sus vestidos e los otros fijos del condestable, eso mesmo, en sus caballos". ( GARCÍA DE SANTA MARÍA, Álvar - Le parti inedite, p. 98). Efectivamente, tras la coronación del rey, los infantes Alfonso y Juan y los hijos del condestable Dávalos, además de otros personajes no citados previamente, fueron armados caballeros (GARCÍA DE SANTA MARÍA, Álvar - Le parti inedite, p. 108).

53. Se trató de su criado García de Herrera, de Pedro Fernández de Hileces, Fernando Manuel, criado del rey de Castilla, Joan Aymerich, Rodrigo de Ledesma y mosén Pin de Xativa (GARCÍA DE SANTA MARÍA, Álvar - Le parti inedite, p. 98).

54. GARCÍA DE SANTA MARÍA, Álvar - Le parti inedite, p. 108. Del mismo modo, a ninguno de los dos se les cita en la crónica en ese punto como armados caballeros pese que algunas páginas antes se anunciaba que así serían investidos, mientras que en los casos de Pedro López Dávalos y Beltrán Dávalos, hijos de Ruy López Dávalos, Diego de Quesada, hijo de Pedro Díaz de Quesada, Diego de Ávila, Fernán Rodríguez de Arévalo, Rodrigo de Avellaneda, Miguel Belome, siciliano, Álvaro Gutiérrez de Vadillo, Joan Mercer y Fernán López, escribano del maestre de Alcántara, a todo ellos expresamente el rey "[...] los armo caballeros" o "[...] armo el dicho señor rey estos caballeros [...]” (GARCÍA DE SANTA MARÍA, Álvar - Le parti inedite, p. 108).

55. GARCÍA DE SANTA MARÍA, Álvar - Le parti inedite, p. 102.

56. PALACIOS MARTÍN, Bonifacio - La Coronación; DURÁN GUDIOL, Antonio - "El rito de la coronación del rey en Aragón". Argensola: Revista de Ciencias Sociales del Instituto de Estudios Altoaragoneses 103 (1989), pp. 17-40, en concreto pp. 27-35; ORCÁSTEGUI GROS, Carmen - "La coronación", pp. 641-645.

57. SUÁREZ FERNÁNDEZ, Luis - Historia del reinado de Juan I de Castilla. Tomo I. Estudio. Madrid: Universidad Autónoma de Madrid, 1977, pp. 25-27; RAMOS VICENT, María del Pilar "Reafirmación del poder monárquico en Castilla: la coronación de Alfonso XI". Cuadernos de Historia Medieval 3 (1983), pp. 3-36, en concreto pp. 26-30; PORRO GIRARDI, Nelly R. - La investidura de armas en Castilla. Valladolid: Junta de Castilla y León, 1998, pp. 279-289; PÉREZ MONZÓN, Olga "Ceremonias regias en la Castilla medieval. A propósito del llamado Libro de la Coronación de los reyes de Castilla y Aragón". Archivo Español de Arte. LXXXIII, 332 (2010), pp. 317-334, en concreto pp. 331-332; CARRERO SANTAMARÍA, Eduardo, "Por las Huelgas los juglares. Alfonso XI de Compostela a Burgos, siguiendo el Libro de la Coronación de los Reyes de Castilla”. Medievalia 15 (2012), pp. 143-157, en concreto pp. 150-152.

58. Los autores citados en la nota anterior plantean dudas en relación a las características de ambas tomas de caballería dentro de las respectivas coronaciones, ya en la catedral Santiago o en el monasterio de las Huelgas de Burgos la de Alfonso XI, ya a cuenta de la existencia o no del Santiago articulado o de su correspondencia con la estatua conservada en el monasterio de las 
Huelgas, aspecto este último que Carrero Santamaría rechaza taxativamente (CARRERO SANTAMARÍA, Eduardo, "Por las Huelgas", p. 151).

59. PALACIOS MARTÍN, Bonifacio - "Investidura de armas de los reyes españoles en los siglos XII y XIII". Gladius. Vol. Especial. Actas del I Simposio Nacional "Las Armas en la Historia (siglos XXIV)" (1988), pp. 153-192, en concreto pp. 185-192. Las fuentes no son claras a la hora de certificar si Alfonso VIII de Castilla acaso ya hubiera procedido a armarse sin intermediación de ningún clérigo.

60. GARCÍA DE SANTA MARÍA, Álvar - Le parti inedite, p. 97.

61. MUÑOZ GÓMEZ, Víctor - Fernando "el de Antequera", pp. 137-138, 154-157, en relación con la promoción del culto mariano por los monarcas castellanos a partir de la consideración de la Virgen como abogada directa, con hitos particulares en los reinados de Alfonso X, Enrique II y Juan I.

62. Durante el torneo de cien contra cien caballeros celebrado el 16 de febrero de 1414, dentro de los festejos de la coronación, cada uno de los grupos se atavió de manera diferenciada con dichos colores (GARCÍA DE SANTA MARÍA, Álvar - Le parti inedite, pp. 127-129). El verde y el rojo también aparece reflejado en las vestimentas en los personajes que representaban a los siete hijos de los reyes Fernando en uno de los entremeses de la entrada de Valencia, además de que el séquito que cerraba el último entremés de dicha entrada representaba a tres personajes femeninos, dos de ellas a caballo y con banderas verdes y rojas, escoltadas por cuatro caballeros, la otra con un estandarte blanco (Documents, Llibre de l'entrada de Ferran d'Antequera, pp. 341-342, 358-359, 374, 376). Francesc Massip se pregunta si no existe alguna relación entre estos colores y los Trastámara (MASSIP BONET, Francesc - “L'entrada valenciana”, pp. 59, 63). A razón de lo observado en mi propio trabajo, sería necesario valorar el simbolismo de los colores ligado acaso a algún concepto abstracto de virtud más que a una conexión de tipo dinástica, por lo menos en relación con el rojo y el verde porque el blanco bien podría evocar el de la divisa de la orden de la Jarra y el Grifo, que se sabe que era blanco y había ocupado un papel central en las entradas triunfales de Fernando "el de Antequera" en Antequera y en Sevilla en 1410 o en Balaguer en 1413 (MUÑOZ GÓMEZ, Víctor - Fernando "el de Antequera”, pp. 147-153; ZURITA, Jerónimo - Anales, Libro XII, cap. XXX, p. 234).

63. En estos juegos de armas, según el relato cronístico de García de Santa María, se aprecia la presencia de "mantenedores" que combaten contra "aventureros" en justas pretendiendo defender un espacio u objeto, no del todo bien determinado en cada uno de aquellos (GARCÍA DE SANTA MARÍA, Álvar - Le parti inedite, pp. 121-122, 129-130). Se trata de elementos propios de los famosos pasos de armas, tan populares en el siglo XV en toda Europa en los medios aristocráticos y con un fuerte valor simbólico en torno a la teatralización realizada del mantenimiento de una promesa o un paso. Un estudio reciente ha podido documentar los primeros pasos de armas con una forma completa descritos por las fuentes precisamente en Castilla, en concreto en 1428, si bien no deja de apuntar la presencia de formas incipientes previamente, citando los propios torneos de las fiestas de la coronación (NADOT, Sébatien - Le Spectacle des joutes. Sport et courtoisie à la fin du Moyen Âge. Rennes: Presses Universitaires de Rennes, 2012, pp. 12 y ss., 28, 129-141). La teatralidad que subyace el paso de armas lo convierte en un espectáculo a tener en cuenta en relación con la transmisión de mensajes cargados de contenido político y acaso no sea casual su promoción en el entorno de Fernando "el de Antequera", aun en una forma incipiente.

64. MASSIP BONET, Francesc - "L'entrada valenciana", pp. 57-58; Documents, Llibre de l'entrada de Ferran d'Antequera, pp. pp. 13, 228, 248, 264-265, 273, 279, 296, 298, 320, 322-323, 325, 327-328, 330, 334, 347, 349, 352-353, 357, 362, 375, 377.

65. MASSIP BONET, Francesc - "L'entrada valenciana", pp. 58-59. En la entrada del príncipe Alfonso en febrero de 1415 la segunda rueda fue modificada, representando a las virtudes, al carecer de sentido la representación de los infantes de Aragón alrededor de su padre, tal y como sí se hizo en las entradas del rey y de la reina. 
66. MASSIP BONET, Francesc - "L'entrada valenciana", pp. 59-61.

67. Mientras, el entremés que cerraba la entrada, llamado "de Mestre Vicent", y que mostraba la visión de Santo Domingo y San Francisco de Cristo con las tres lanzas estaba revestido de un simbolismo fundamentalmente profético y escatológico, ligado a la predicación de Vicente Ferrer en relación al fin de los Tiempos y el Juicio Final. Aunque su lectura no sería fundamentalmente política, bien puede entenderse que ayudaba a entroncar el orden temporal en el que encajaba el rey como parte de la globalidad del plan divino de la Creación y hacia la salvación del ser humano frente al pecado, la muerte y el Mal (MASSIP BONET, Francesc - "L'entrada valenciana", pp. 62-63).

68. CANCIONERO DE JUAN ALFONSO DE BAENA. Ed. José María Azáceta. Madrid: CSIC, 1966, pp. 1.009-1.013.

69. Junto con los ejemplos ya citados, puede ser ilustrativa la profusión de pendones con las armas de Aragón en las celebraciones del 29 de junio de 1412 en Cuenca al conocerse la proclamación del infante Fernando como nuevo rey de Aragón (PANZÁN, Luis - Recordanzas, pp. 100-103)

70. Particularmente esclarecedores en este sentido SESMA MUÑOZ, José Ángel - El Interregno (1410-1412), pp. 146-224, hasta el punto de concluir su estudio el profesor Sesma insistiendo, como conclusión, que el ascenso al trono de Fernando I no abrió una nueva etapa en la evolución institucional, política, social y económica de la Corona de Aragón y “[...] ni siquiera se puede hablar de un cambio de dinastía. La Casa Real de Aragón seguirá en el trono, al menos durante el siglo XV". (p. 224); Igualmente, MORALES ARRIZABALAGA, Jesús - "La publicación de Fernando de Castilla como Rey de Aragón. El ‘Compromiso de Caspe' de 1412 como cuestión de justicia”. in SESMA MUÑOZ, José Ángel (dir. científico) - La Corona de Aragón en el centro de su Historia 1410-1412, pp. 315-346, donde se procede al análisis desde la teoría jurídica contemporánea en los reinos ibéricos de la Corona de Aragón del sentido de la decisión tomada en Caspe.

71. Puede ser el caso de la entrada real en Perpiñán para las vistas con el emperador Segismundo, en la medida en que se sabe que, a la llegada de éste a la ciudad el 19 de septiembre de 1415 "[...] la Cibdad embió los juegos con que rescibieron al Rey [...]” (PÉREZ DE GUZMÁN, Fernán - Crónica, Año 1415, Cap. XII, p. 365).

72. BOULTON, D'Arcy J. D. - The Knights of the Crown: The Monarchical Orders of Knighthood in Later Medieval Europe 1325-1520. Woodbridge: Boydell Press, 2000, pp. 330-338.

73. La difusión de la divisa de la Jarra y el Grifo entre caballeros de todo el Occidente, sólo mejor documentada por lo que se refiere a casos procedentes del Imperio, Bohemia, Hungría y Polonia, hasta el inicio del siglo XVI, cuando igual que la Banda de Castilla pasase a verse eclipsada por el protagonismo adquirido por la orden del Toisón de Oro en el reinado de Carlos I, la relevancia de sus principios y de su simbolismo ceremonial en la corte aragonesa sino también su valor en el establecimiento de relaciones diplomáticas en los entorno aristocráticos del continente (VENDRELL GALLOSTRA, Francisca - "Caballeros centroeuropeos"; CORETH, Anna - "Orden von Stola und den Kanndeln und dem Greifen (Aragonesischer Kannenorden)". Mitteilungen des Oesterreichischen Staatsarchivs 5 (1952), pp. 34-62; HYE, Franz-Heinz von - "Testimonios sobre órdenes de caballería españolas en Austria y estados vecinos (Bohemia, Alemania, Suiza y Hungría)". En la España medieval 16 (1993), pp. 169-187; SALICRÚ I LLUCH, Roser - "Caballeros cristianos en el Occidente europeo e islámico". in HERBERS, Klaus, JASPERS, Nikolas - "Das kommt mir spanisch". Eigenes und Fremdes in den deutsch-spanischen Beziehungen des spaten Mittelalters. Münster: Lit Verlag, 2004, pp. 217-289. Sobre las divisas reales en la Corona de Aragón desde el final del siglo XIV, MASSIP BONET, Francesc - A cos de rei, pp. 122-134; DOMENGE I MESQUIDA, Joan - "Las joyas emblemáticas de Alfonso V". Anales de Historia del Arte 14, Número especial (2014), pp. 99-117; NARBONA CÁRCELES, María - “Ay!... las divisas de Carlos de Evreux, Príncipe de Viana (1421-1461)”. Príncipe de Viana. Vol. 72, 253 (2011), pp. 357-374; NARBONA CÁRCELES, María - "El contenido devocional de las divisas: el azafrán y la olla ardiente de la reina de Aragón 
(1416-1458)". Emblemata. Revista Aragonesa de Emblemática 20-21 (2014-2015), pp. 435-452; MARTÍNEZ LLORENTE, Javier - “Divisas y heráldica”, pp. 180-187.

\section{RESÚMENES}

A 28 de junho de 1412, como resultado do Compromisso de Caspe, o infante D. Fernando de Castela foi proclamado rei de Aragão depois de dois anos de interregno. As possíveis necessidades de legitimação do direito ao trono e do exercício do poder real de Fernando enquanto sucessor de Martinho I derivaram num espetacular programa propagandístico. Neste artigo propõe-se uma análise dos princípios fundamentais da linguagem simbólica usada pelo rei D. Fernando de Aragão para este fim. Para tal, parte-se do estudo das principais cerimónias públicas protagonizadas pelo monarca durante o seu breve reinado (1412-1416), com destaque para as entradas reais nas principais cidades da monarquia e para as festas da sua coroação em Saragoça em fevereiro de 1414.

On 28 June 1412, as a result of the compromiso of Caspe's sentence, the infante Ferdinand of Castile was proclaimed king of Aragon after two years of interregnum. Ferdinand's potential needs to legitimise his right to the throne and his exercise of royal authority as king Martin I's successor conducted to an spectacular propaganda apparatus. This paper aims to analyse the core principles of the symbolic language which was performed to this goal by king Ferdinand I of Aragon. This purpose is based on the study of the main public ceremonies that were led by the monarch during his brief reign (1412-1416), prominently royal entries in the major cities in the Aragonese monarchy and Coronation festivities at Zaragoza in February 1414.

\section{ÍNDICE}

Palavras-chave: Coroa de Aragão, Fernando I, legitimação, comunicação política, cerimónias reais Keywords: Crown of Aragón, Ferdinand I, legitimation, political communication, royal ceremonies

\section{AUTOR}

\section{VÍCTOR MUÑOZ GÓMEZ}

Universidad de La Laguna, Facultad de Humanidades, Instituto de Estudios Medievales y Renacentistas, 38200, San Cristóbal de La Laguna (S. C. de Tenerife), Espanã vmunozgo@ull.edu.es 